\title{
BANK SYNDICATES AND LIQUIDITY PROVISION
}

\author{
Joao A. C. Santos \\ S. Vish Viswanathan \\ Working Paper 27701 \\ http://www.nber.org/papers/w27701 \\ NATIONAL BUREAU OF ECONOMIC RESEARCH \\ 1050 Massachusetts Avenue \\ Cambridge, MA 02138 \\ August 2020
}

We thank Manuel Adelino, Teodora Paligorova and Murillo Campello for valuable comments. The views stated herein are those of the authors and are not necessarily those of the Federal Reserve Bank of New York, the Federal Reserve System, or the National Bureau of Economic Research.

NBER working papers are circulated for discussion and comment purposes. They have not been peer-reviewed or been subject to the review by the NBER Board of Directors that accompanies official NBER publications.

(C) 2020 by Joao A. C. Santos and S. Vish Viswanathan. All rights reserved. Short sections of text, not to exceed two paragraphs, may be quoted without explicit permission provided that full credit, including $(\subset$ notice, is given to the source. 
Bank Syndicates and Liquidity Provision

Joao A. C. Santos and S. Vish Viswanathan

NBER Working Paper No. 27701

August 2020

JEL No. G21,G23,G3

\begin{abstract}
$\underline{\text { ABSTRACT }}$
We provide evidence that credit lines offer liquidity insurance to borrowers. Borrowers are able to extensively use their credit lines in recessions and ahead of credit line cuts. In fact drawdowns and changes in drawdowns predict internal credit rating downgrades and credit line cuts, suggesting substantial liquidity access before credit line cuts. Credit line cuts are concentrated on borrowers who do not use credit lines, and when they occur they still leave borrowers with funds to draw down. Building on this evidence, we develop a model where syndicates faced with liquidity shocks continue to support credit line commitments due to the continuation value of their relationship with borrowers. Our model yields a set of predictions that find support in the data, including the substantial increase in the lead bank's retained loan share and in the commitment fees on the credit lines issued during the financial crisis of 2008-09. Consistent with the model, credit lines with higher expected drawdown rates pay higher commitment fees, and lead banks often increase their credit line investments in response to the failure of syndicate members, reducing borrowers' risk exposure to bank failures.
\end{abstract}

Joao A. C. Santos

Federal Reserve Bank of New York

33 Liberty St

New York, NY 10045

joao.santos@ny.frb.org

S. Vish Viswanathan

Duke University

Fuqua School of Business

100 Fuqua Drive

Durham, NC 27708

and NBER

viswanat@duke.edu 


\section{Introduction}

Do credit line commitments by syndicates provide liquidity to firms that need it? Or does liquidity evaporate when firms need it the most? These questions have been the subject of an intense debate in the academic world. Starting with Roberts and Sufi (2009), a literature has emerged that shows that covenant violations lead to substantial reductions in credit line commitments, suggesting that credit lines offer only limited liquidity insurance. A related literature going back to Sufi (2009) arrives at a similar conclusion by investigating firms' choices between cash and credit lines. However, this body of research takes an ex post view of loan commitments and does not answer the key question as to whether credit lines actually provide liquidity insurance. The key insight from this literature raises a puzzle: why did firms not raise liquidity in a precautionary way by drawing down credit lines before reporting the information that will trigger the covenant violations leading to liquidity cuts? Is it possible that these firms did draw down their credit lines preemptively? Further, these studies do not consider the supply channel and investigate why and when banks keep their credit line commitments.

These questions gained additional prominence with the wave of corporate drawdowns following the Covid-19 outbreak in the US. Between March 12 and April 9, 2020, 452 corporations drew $\$ 218$ billion on their credit lines according to S\&P LCD. 110 of those corporations experienced a credit downgrade or were put on rating agencies' watch list. Among these, the drawdown rate was 0.77 for those that accessed their credit lines before or on the day of rating agencies' action (downgrade or inclusion in the watch list) and 0.75 for those that did it afterwards (Figure 1) 1 While this is not a statistical test, it is related to the key point we want to make in the paper, that substantial liquidity is available to firms that need it via credit lines.

Specifically, in this paper, we contribute to the literature on the liquidity insur-

\footnotetext{
${ }^{1}$ For the 342 borrowers that were not downgraded or were not in the rating agencies' watch list, the average drawdown rate was 0.62 .
} 
ance role of credit line commitments. We begin by investigating a set of questions that speak to the liquidity insurance role of credit commitments from an ex ante point of view. Do borrowers accelerate drawdowns in a precautionary way anticipating events that may impede them from accessing their credit lines? Do syndicates allocate credit line cuts in a way to preserve credit lines to those firms that need them? We then develop a theory of optimal syndicate formation in which syndicates receive liquidity shocks but still provide liquidity insurance to firms. We end by testing some predictions of our model about (i) the pricing of credit lines,(ii) the structure of credit line syndicates, and (iii) the effect of shocks that inhibit syndicate members to meet their liquidity commitments.

We capitalize on data from the Shared National Credit (SNC) program to investigate the liquidity insurance role of credit lines. This program tracks credit lines annually. This allows us to observe if and when borrowers draw down on their credit lines, and when credit commitments experience cuts. Since our sample covers the 1998 to 2013 time period we are able to analyze credit lines' drawdowns and cuts over the course of three recessions. Further, since our data contains comprehensive information on credit line syndicates we are able to investigate lead banks' loan share decisions and how shocks to syndicate members affect credit lines.

We show that in aggregate firms draw down credit lines substantially more in recessions and while credit lines experience cuts, these tend to occur towards the end of recessions; suggesting that cuts occur subsequent to drawdowns. The drawdown result is robust in a regression where we saturate our specification with borrower-, loan- and bank-specific controls and allow for both bank and firm fixed effects. This shows that firms are able to utilize their credit lines when they likely need them the most. While the poor performance of firms leads to cuts in credit lines, these cuts appear to lag and emerge after substantial liquidity has already been provided to firms. Indeed, we show using a regression specification with controls that drawdowns and changes in drawdowns 
predict credit line cuts; i.e., there is information in the drawdown beyond that in the controls and firm and bank fixed effects.

The previous evidence focuses on borrowers' ability to utilize their credit lines. A complementary way to ascertain the liquidity insurance role of credit lines it to look at banks. Suppose that banks in credit line syndicates experience shocks and decide to cut credit lines as a result, which credit lines do they cut? We show that cuts occur more disproportionately on firms that do not drawdown; further even for such firms there is substantial unused credit line capacity subsequent to the cut. This suggests that firms that anticipate liquidity needs have had the opportunity to do so ahead of credit line cuts. Consistent with this idea, we show that while cuts in credit lines are contemporaneous with (or lag) internal credit line downgrades, drawdown rates increase ahead of downgrades. This evidence clearly shows that borrowers are able to capitalize on their credit lines before banks downgrade them and cut their size.

Altogether, the evidence we present in the first part of our paper shows that credit lines provide substantial liquidity to firms. This contrasts with the ex post view prevalent in the literature that credit lines do not offer sufficient liquidity insurance because banks cut them subsequent to negative news (often after covenant violations, see for example Roberts and Sufi (2009) and Chodorow-Reich and Falato (2018)).

In the second part of our paper, we build on this evidence and present a theory of loan syndicates that speaks to the credibility of delivering liquidity insurance to borrowers with credit lines and the allocation of credit lines and fees to the lead and syndicatemember banks. We assume that syndicate members receive supply shocks (possibly net worth shocks as in Holmstrom and Tirole (1997) and Rampini and Viswanathan (2019a). These supply shocks make the ex post provision of liquidity insurance at the committed interest rate difficult because they increase the syndicate member's ex post cost of capital. Offsetting this cost hike is the continuation value of the relationship with the firm to the syndicate member, which varies between the lead and the other members of 
the syndicate. Following Ray $(2002)$ and Board (2011), we design the optimal syndicate and show that it depends on the cost of capital for syndicate members after the supply shock and how much they discount the future and care for their relationship with the borrower.

Our theory yields several predictions. For example, commitment fees should go up after bank supply shocks (such as recessions) and larger loans should have larger syndicates. Further, given lead banks tend to have relatively lower costs of capital following supply shocks and relatively greater continuation value for the relationship, then they should retain a larger portion of the credit line following supply shocks and receive a greater share of the commitment fee. Further, given a fixed syndicate size, a contraction in credit from non-leads in a syndicate should be partially offset by a credit increase from the lead bank in a syndicate.

In the last part of our paper, we provide supporting evidence for some predictions of our model. For example, we document that larger credit lines have larger syndicates, consistent with the sharing of supply shock risk in our model. Also consistent with our model, we document that borrowers with a track record for using their credit lines extensively pay higher commitment fees on new credit lines. Using recessions as our proxy for bank supply shocks, we document that commitment fees, the price banks charge for granting borrowers access to liquidity when they extend credit lines go up in recessions. Additionally, we show that the share of the credit line that the lead bank retains increases during recessions, consistent with our model insight on lead banks response to supply shocks. These effects are particularly evident during the 2008-2009 recession when the banking system was under stress.

Our last test builds on the failure of a syndicate member bank to investigate the prediction of our model on shocks to non-lead banks. We show that in a substantial number of cases, the syndicate lead provides additional funding to the credit, thereby reducing the size of the credit line cut induced by non-lead bank failure. This is consistent 
with our model that suggests that leads will only partially offset the lost credit from nonleads. Overall, our evidence shows that while the insurance they provide is incomplete, syndicates play a key role in providing such liquidity insurance to borrowers, allowing them to retain access to a higher fraction of their lines of credit when banks experience shocks.

Our paper contributes to the large debate on the liquidity insurance that credit lines provide borrowers. A strand of this literature argues that lines of credit are distinct from the committed lines of credit defined in the theoretical literature because they are contingent on borrowers' performance. For example, Roberts and Sufi (2009) and Sufi (2009) find that covenant violations lead to substantial reductions in credit line commitments. Sufi (2009) documents that firms with high levels of cash flow rely on lines of credit whereas firms with low levels of cashflow rely on cash and argues high cash flow is critical to avoid covenant violations, which trigger reductions in the size of unused credit lines. Chodorow-Reich and Falato (2018) argue that credit lines were cut post the financial crisis of 2008-2009 for firms that had covenant violations.2

Another set of studies argues that banks' inability (or willingness) to supply funds hinders the liquidity insurance of credit lines. Ivashina and Scharfstein (2010a) used Dealscan data and document an increase in drawdowns between mid-August 2008 and December 2008 and note that in several instances firms state that they drew on credit lines to enhance their liquidity during the credit crisis. Huang (2010) finds that credit lines of more distressed banks at the beginning of the crisis experienced lower utilization rates. However, none of these studies has information about both borrowers and their credit line providers, which makes it difficult to ascertain the effect of banks on borrowers' access to liquidity under their lines of credit. $3^{3}$ Acharya et al. (2013) avoid

\footnotetext{
${ }^{2}$ See Flannery and Lockhart (2009), Yun (2009), Campello et al. (2010), Campello et al. (2011), Lins et al. (2010), and Acharya et al. (2012) for other studies arguing that cash and credit line availability are not good substitutes. Berrospide (2012) find that large unused commitments were a key determinant of increased precautionary liquid
buffers that large US banks built during the 2008-09 financial crisis, suggesting that banks factor in their exposures to the credit lines they granted.
} 
this challenge by focusing on the role of the banking sector. They point out that credit line use is subject to an aggregate liquidity risk because the banking sector is not able to meet the liquidity demands of the entire corporate sector. Consistent with this idea, Demiroglu et al. (2012) document that borrowers' access to lines of credit is contingent on the banking sector's lending standards.

Several studies have uncovered supporting evidence for the liquidity role of credit lines. For example, Jiménez et al. (2009) and Norden and Weber (2010) document based on Spanish and German data, respectively, that firms increase utilization of their credit lines significantly in the period leading up to default. Chen et al. (2017) find, using data on the actual draw down rates from US firms' 10-K reports, that firms are more likely to draw down credit lines than obtaining new loans during times of greater short-term financing needs. Kizilaslan and Mathers (2014) argue, based on a model they develop to predict drawdowns, that unexpected drawdowns are predictive of decreased future cash flows and covenant violations 4

Our paper adds to this body of empirical research in several ways. Our paper uses both bank and borrower information on credit lines and their utilization at a level of detail not available previously. In contrast to those studies which evaluate the liquidity insurance of credit lines based on borrowers' ex post access to credit lines, our evidence based on an ex ante view of credit lines shows firms do receive substantial liquidity from their lines of commitment. Our evidence adds support to those studies which argue that the financial condition of banks affects the liquidity insurance of credit lines, but here too our findings show the importance of factoring in borrowers' "precautionary drawdowns" in assessing borrowers' exposure to the financial condition of their credit line providers. Our findings also show the importance of accounting for the role of syndicate members, in particular the lead bank, in fully accessing that exposure.

Our paper also adds to existing studies of commitment fees on credit lines. Shock-

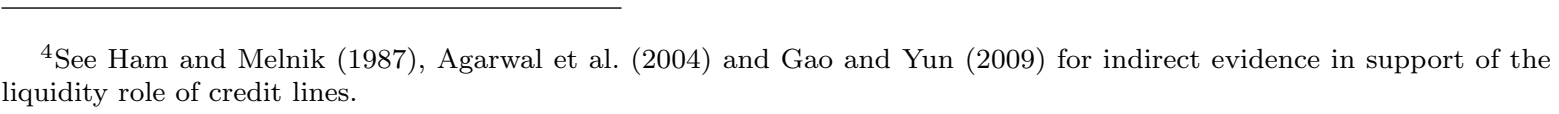


ley and Thakor (1997), Chava and Jarrow (2008), and Gatev and Strahan (2006) study the role that borrower-specific factors and loan-commitment-specific factors play on credit lines' undrawn fees. We control for those factors, but focus instead in identifying how recessions, our proxy for bank shocks, affect the way banks set these fees. In this regard, our paper is closer to Bord and Santos (2014) who document that banks that experience a liquidity shock following the 2007 collapse of the asset-backed commercial paper increased the undrawn fees on the credit lines they granted borrowers. We also expand those studies by documenting that banks factor in borrowers' drawdown experiences when they set the commitment fees on their credit lines.

Lastly, our paper adds to the literature on credit line syndicates, in particular studies of lead banks' loan shares. Ivashina and Scharfstein (2010b) documents that lead banks retain larger shares of loans they originate during crises periods, in particular during the 2008-2009 recession, while looking at a sample of both syndicated term loans and credit lines, and argue this is a contributing factor to amplify credit cycles. Paligorova and Santos (2019), in turn, document that lead banks' term-loan shares have evolved very differently from their credit-line shares, with the former depicting a distinct downward trend induced by the growing presence of shadow banks in term-loan syndicates. We too find that lead banks retain larger shares of loans originated during crises periods but based on a sample of credit lines, a finding we argue is consistent with our theory of syndicates.

The rest of our paper is organized as follows. Section 2 describes our data and characterizes our sample. Section 3 presents the results of a series of tests we developed to show that credit lines do offer substantial liquidity to borrowers. Section 4 presents a model where syndicates faced with liquidity shocks continue to support credit line commitments due to the continuation value of the relationship with borrowers while Section 5 presents evidence consistent with the predictions of our model. Section 6 concludes with some final remarks. Appendix 6 provides proofs of propositions in the 
paper while Appendix 6 provides the definition of empirical variables used in the paper.

\section{Data and Sample Characterization}

\section{$2.1 \quad$ Data}

The main data source for this project is the Shared National Credit (SNC) program run by the Federal Deposit Insurance Corporation, the Federal Reserve, and the Office of the Comptroller of the Currency. SNC tracks, at the end of each year, confidential information on all syndicated credits -new as well as credits originated in previous years -that exceed $\$ 20$ million and are held by three or more federally supervised institutions. ${ }^{5}$ For each credit, the program reports the identity of the borrower, the credit type (credit line vs. term loan), its purpose (working capital, debt repay, M\&A, among others), origination amount and date, maturity date, bank rating, drawdown amount, and complete information about the syndicate, including investors' loan shares. We use this data to identify borrowers' with credit lines and to get information on their drawdowns. We also use it to track changes in the loan rating and in the syndicate composition over the life of the loan.

We merge SNC with Compustat and the Center for Research in Security Prices (CRSP) to get information on borrowers financials and stock prices, respectively. SNC contains loans from privately-held and publicly-held firms, but Compustat is dominated by publicly-held firms. As a result, when we account for borrowers' financials we exclude credit lines to privately-held firms from our sample. We also match SNC with Reports of Condition and Income to get financial information for the lead bank in the syndicate. Wherever possible we obtain bank data at the holding company level using the Y9C reports. If these reports are not available we rely on Call Reports which have data at the bank level.

\footnotetext{
${ }^{5}$ The confidential data were processed solely within the Federal Reserve System for the analysis presented in this paper.
} 
We use NBER business cycle expansion and contraction dates to identify the beginning and end of economic recessions during our sample period. We rely on FDIC information on bank failures to investigate the impact a syndicate member failure on the liquidity that credit lines offer their borrowers. We restrict this exercise to bank failures because (with the exception of Bear Stern and Lehman) we do not have comprehensive information on nonbank failures. This is not a problem because as we will see banks are the dominant investors in credit line syndicates.

Finally, given that SNC does not gather information on loan rates, we rely on Loan Pricing Corporation's Dealscan to investigate the pricing of credit lines. In contrast to SNC, Dealscan gathers information on all syndicated credits, though, only at the time of their origination $\sqrt{6}$ As with SNC, we merge Dealscan with Compustat, CRSP and Reports of Condition and Income.

\subsection{Sample Characterization}

Table 1 reports information on nonfinancial corporations' credit lines included in the SNC data. The data cover 36,096 credit lines from 1988 to 2013 for a total of 109,592 loan-year observations; our unit of analysis is the loan-year. While the coverage of SNC loans increases over time, on average we have three to six thousand credit lines each year. A credit line may drop from the SNC data set before the maturity date for various reasons, including not meeting the minimum reporting conditions, or being canceled by the borrower or the lender. We are cognizant of this potential incompleteness in our panel, but it is not clear it drives our key results. For example, it is likely easier for banks to cancel credit lines that have not been tapped by borrowers, but that suggests these borrowers did not need liquidity support. There are a total of 19,294 distinct corporate borrowers represented in our data with 2,446 to 4,682 firms in any given year. The number of lead banks varies from 113 to 260 over the sample period with a total of

\footnotetext{
${ }^{6}$ See Bord and Santos (2012) for a comparison between the SNC and Dealscan databases.
} 
588 unique banks.

The top panel of Table 1 reports information on the credit lines and their syndicates. The average drawdown rate is $38 \%$, with the 10 th and 90 th percentiles being $0 \%$ and $100 \%$, respectively. $13 \%$ of the credit lines are fully utilized (i.e. the borrower has used at least $95 \%$ of the credit line). The average credit line is $\$ 223$ million and has three years left before it reaches its maturity date. About $88 \%$ of the credit lines are rated PASS by the lead bank, and borrowers take out credit lines most often for working capital purposes.7 On average, the lead bank owns $25 \%$ of the credit line, but the 10th and 90th percentiles are $0 \%$ and $50 \%$, respectively. There is also significant variation in the size of syndicates. The average syndicate has 9 banks, but the 10th and 90th percentiles have 3 and 9 banks, respectively.

Turning to the middle panel, which reports information for the lead bank, we see that the average bank has assets worth $\$ 527$ billion, with the 10th and 90th percentiles equal to $\$ 28$ billion and $\$ 2$ trillion, respectively. There is a large variation in the size of lead banks in our sample, but it includes some of the largest banks in the country. The average bank has an $8 \%$ equity-to-assets ratio, with the 10th and 90th percentiles equal to $5 \%$ and $11 \%$, respectively. In line with the assertion that banks have a comparative advantage in granting credit lines because of their deposit funding, we see that the average bank in our sample has a deposit-to-asset ratio equal to $58 \%$ and the 10 th percentile of the deposit distribution is equal to $40 \%$.

Finally, looking at the bottom panel of Table 1, which reports information for the set of publicly listed borrowers in our sample, we see that the risk of the borrowers is more disperse than what the high portion of loans rated as PASS may suggest. For example, the average borrower has a leverage ratio of $33 \%$ with the 90th percentile equal to $57 \%$. Also, the 10th percentiles of the profit margin and stock returns are both negative. Further, even though we have firm ratings for only about $18 \%$ of the sample,

\footnotetext{
${ }^{7}$ Banks rate loans (including portions of the loan) into five categories: PASS, SPECIAL MENTION, SUB STANDARD, DOUBTFUL and LOSS, with PASS being the highest category.
} 
we see that among these, $11 \%$ are rated investment grade with the remaining $7 \%$ being rated below grade. This dispersion in risk is important because risky borrowers place more value on the liquidity provided by credit lines than safer firms.

\section{Do Credit Lines Provide Liquidity Insurance?}

Data limitations have made it difficult to disentangle the demand and supply drivers of borrowers' utilization of credit lines and thus ascertain the extent of the liquidity insurance that credit lines provide borrowers. For example, if a borrower experiences a cut in its credit line which is triggered by the violation of a covenant in the loan contract that does not necessarily constitute evidence against credit lines' liquidity insurance role. However, if in contrast, that cut emerges because the bank (or a member of the syndicate) is experiencing financial difficulties, this would constitute evidence of a reduction in the liquidity insurance role of credit lines.

In this section, we present a set of novel results that are relevant to this debate by looking at the joint behavior of credit line drawdowns and credit line cuts. We begin by investigating the role of banks in the provision of credit lines. Next, we document borrowers' ability to draw down their credit lines in recessions, arguably when they need liquidity the most. We also show that credit line cuts tend to occur subsequent to drawdowns and that firms avail of substantial credit prior to drawdowns even when bank's internal ratings involve downgrades. After that, we study whether banks actively manage their credit lines either by cutting their size or through their credit ratings and how corporate borrowers respond. Thus, we provide novel evidence on both firm and bank behavior to understand the dynamics of credit line drawdowns and cuts. 


\subsection{Who funds Credit Lines?}

Credit lines provide liquidity insurance to borrowers only to the extent that they are funded by investors that will be able to meet borrowers' liquidity needs when they attempt to utilize them. This likely explains why credit lines continue to be predominantly funded by banks. Over the last two decades credit lines outgrew term loans in the US (Figure 2, left graph). Despite that growth, and in contrast to term loans, banks continue to fund almost entirely all of the credit lines they grant corporations (Figure 2, right graph). In 1988, banks funded $91 \%$ and $96 \%$ of outstanding term loans and credit lines, respectively. By 2013, the percentage of term loans funded by banks had declined to $42 \%$ while the percentage of bank-funded credit lines remained at $96 \%$.

Another important condition for credit lines to meet their liquidity function is for them to maintain a stable investor base over their life. Indeed, over the last two decades investor turnover in credit-line syndicates remained very low and driven by exchanges of loan positions between banks (see Figure 3). This stands in sharp contrast with investor turnover in term-loan syndicates, which kept increasing with the growth of the secondary loan market and the growing presence of nonbank investors in this market.

\subsection{Drawdowns During Recessions}

A more direct way to ascertain whether credit lines provide liquidity insurance is to investigate whether borrowers are able to use them when they need funding. As such, we should see an increase in drawdowns during recessions. Indeed, there is a distinct increase in both drawdown rates and the percentage of credit lines fully drawndown during the three recessions the US experienced in the last two and a half decades (Figure 4). Importantly, these swings are not driven by potential changes in the size of the credit line over time because as the figures show we continue to find a similar pattern when we restrict the analysis to credit lines which size (i.e. the commitment amount) remains unchanged from one year to the next. 
We use the following model to investigate the cyclical pattern of drawdowns more closely:

$$
\begin{aligned}
\operatorname{DRAWDOWN} \operatorname{RATE}_{f, l, b, t} & =c+\alpha \operatorname{RECESSION} N_{t}+\beta X_{f, t-1}+\gamma Y_{l, t-1} \\
& +\eta Z_{b, t-1}+\epsilon_{f, l, b, t}
\end{aligned}
$$

where $D R A W D O W N R A T E_{f, l, b, t}$, is the drawdown rate at the end of year $t$ by firm $f$ on credit line $l$ it took out from bank $b$. The key variable of interest in that specification is RECESSION, a dummy variable equal to 1 for the years that coincide with the three NBER recessions during our sample period. We also break down this dummy variable into three separate dummy variables, one for each of the three NBER recessions (1990/91, 2001, and 2008/09). We attempt to identify the impact of recessions on borrowers' drawdowns controlling for the borrower-, loan- and lead bank specific factors, $X, Y$, and $Z$, respectively, reported in Table 2 .

The results of this investigation are reported in Table 2. The top panel reports univariate results. The middle panel reports results of our multivariate analysis. In the bottom panel, we modify (1) and replace the dependent variable with a dummy variable equal to one if the borrower has fully drawndown its credit line. Throughout the three panels, columns (1) and (4) report the results of a pooled analysis while columns (2) and (5) report results estimated with bank fixed effects. Columns (3) and (6) report the results when we consider bank-borrower fixed effects.

Looking at the top panel of Table 2, we see that RECESSION is positive and significant with coefficients ranging from 0.04 to 0.06 . This shows that drawdown rates increase during recessions by 4 to 6 percentage points, the equivalent of 10 to $16 \%$ of the sample mean $(38.25 \%)$. When we use separate dummy variables to isolate the effects of the three recessions, we see that they all come out positive and significant with coefficients ranging from 0.02 to 0.08 . On close inspection, we see that the coefficients 
on the 1990/91 and 2008/09 recession dummy variables are always larger than those on the 2001 variable, possibly because the latter recession was shorter and not as deep as the other two.

The key insights from the univariate analysis persist in our multivariate analysis (middle panel of Table 2). The coefficient on RECESSION continues to be positive and significant, albeit a bit smaller (0.03). Nonetheless, that increase of 3 percentage points still corresponds to $12 \%$ of the sample mean used in the multivariate analysis (26.08\%). Looking at the columns with the separate variables for the three recessions, we see that the dummy variable for the 2001 recession is never significant. The dummy variable for the 1990/91 recession is always positive, but it is significant in only one of the three models we consider. In contrast, the dummy variable for the 2008/09 recession is positive and significant for all three models. According to our estimates, drawdown rates increased by 5 percentage points during the 2008/09 recession, the equivalent of $19 \%$ of the sample mean.

In the interest of space we do not report in Table 2 the controls we use in our multivariate analysis, but those that are significant are consistent with our priors. For example riskier borrowers, as captured by leverage, tangible assets, interest coverage and stock volatility, have higher drawdown rates on their credit lines. In contrast, larger borrowers or borrowers with higher liquidity have lower drawdown rates. Among the bank controls, only size is systematically significant and indicates that borrowers of larger banks on average have lower drawdown rates, a result likely driven by the fact that larger borrowers (which tend to have lower drawdown rates) usually take out credit lines from larger banks. With regards to the loan controls, we see that riskier credit lines as defined by the bank rating, and credit lines with more years until maturity have higher drawdown rates. Credit lines for M\&A, capital expenditures and to repay debt have higher drawdown rates. In contrast, credit lines to back up commercial paper programs have on average lower drawdown rates. 
Looking at the bottom panel of Table 2, we see that our results on fully drawndown credit lines mimic our findings on drawdown rates. There is an increase in the incidence of credit lines that are fully drawndown during recessions. Again, we find that this effect while present in the 1990/91 recession is more prevalent in the 2008/09 recession.

In sum, our evidence that drawdown rates, in particular our finding that the percentage of fully utilized credit lines, increases during recessions arguably when borrowers need funding the most is suggestive that credit lines provide liquidity insurance to borrowers. This evidence is not driven by potential reductions in the size of credit lines that might occur during recessions 8 Further, it continues to hold when we do the analysis within banks and also when we condition it to borrowers that have credit lines from the same bank over time. Our findings, however, suffer from the limitation that is common to most of the existing studies of credit lines' liquidity role: it is based on the ex-post utilization of credit lines. In the next subsection, we present the results of some tests that are less exposed to this limitation.

\subsection{Do Banks Actively Manage Credit Lines?}

Credit lines' drawdown rates are the outcome of both the demand for funding by borrowers and banks' willingness to let borrowers utilize their credit lines. In what follows, we investigate two variables which are more likely to be under banks' control, and which affect borrowers' ability to access their credit lines: cuts to the size of credit lines and banks' internal rating of credit lines.

\subsubsection{Managing the Credit Line Size}

In our data we are able to observe whether credit lines experience cuts in their commitment amount. These cuts could be borrower driven (for example to save on the costs of

\footnotetext{
${ }^{8}$ The findings we report in Table 2 continue to hold when we restrict the sample to credit lines which size does not change from one year to the next (see Table IA.1 of the Internet appendix).
} 
maintaining a credit line) or bank driven (for example to reduce the liquidity pressure from borrowers' drawdowns). Nonetheless, it is still worth investigating whether these cuts tend to lead or lag borrowers' drawdowns. While the former suggests banks activity manage borrowers' access to credit lines, the latter indicates borrowers are able to utilize at least to some extent their credit lines before banks intervene to limit drawdowns.

In the previous section, we documented that drawdown rates increase significantly during recessions. Figure 5 plots both the annual time series of drawdown rates and the percentage of credit lines that experience a cut. As we can see from that figure, both drawdown rates and the incidence of cuts increase significantly during recessions. However, the former reaches a maximum before the latter in all three recessions in our sample, suggesting that borrowers are able to drawdown their credit lines before these are cut.

We investigate the hypothesis that credit line cuts leg borrowers' drawdown activity more closely using the following model:

$$
\begin{aligned}
C U T_{f, l, b, t} & =c+\alpha D R A W D O W N R A T E_{f, l, b, t-1}+\beta X_{f, t-1}+\gamma Y_{l, t-1} \\
& +\eta Z_{b, t-1}+\zeta T_{t}+\epsilon_{f, l, b, t}
\end{aligned}
$$

where $C U T$ is a dummy variable equal to one if the credit line experiences a cut in its size in year $t$. DRAWDOWN RATE is the drawdown rate on the credit line at the end of year $t-1$. In another specification, we control instead for the drawdown rate at the end of the year $t-2$ and for the log of the additional dollar amount the borrower draws down during year $t-1$. We estimate model (2) controlling for our sets of loan-, borrower- and bank-specific factors, $X, Y$, and $Z$, respectively, and for a set of year dummy variables, T. Further, we estimate model 2 both without and with loan fixed effects. We also consider a specification with loan and bank fixed effects.

The results of this investigation are reported in Table 3. Columns (1) and (4) 
report the results of a pooled analysis while Columns (2) and (5) report results estimated with loan fixed effects. Columns (3) and (6), in turn, report results estimated with loan and lead-bank fixed effects. Looking at Columns (1) through (3) we see that $D R A W D O W N R A T E_{t-1}$ is always positive and statistically significant. A higher (lagged) drawdown rate increases the odds of a future cut in the credit line. Turning our attention to Columns (4) through (6) we see that DRAWDOWN RATE $E_{t-2}$ is always positive and statistically significant, and $L D R A W N A M T$, the log of the dollar amount the borrower draws down between $t-2$ and $t-1$, is always positive and statistically significant in two out of our three models. Borrowers that increase drawdowns in a year are more likely to experience a reduction in the size of their credit line in the following year. These results suggest banks are slow at cutting credit lines; by the time they intervene, borrowers have already utilized to some degree their credit lines.$^{9}$

The previous analysis focuses on the incidence of cuts, but it is silent with regards to the size of the cut. In particular, how much is left untapped in credit lines after the cut? To get an answer to this question, we start by plotting in Figure 6, left graph, the undrawn rate in the credit line after the cut against the undrawn rate the borrower had beforehand 10 The average (median) undrawn rate before the cut is $51 \%(47 \%)$. After the cut, these figures drop to $35 \%$ (28\%). While the reduction in undrawn rates is sizable, it is also the case that borrowers are still left with significant portions untapped in their credit lines. Further, and importantly, as we can see from the graph the biggest cuts are concentrated on credit lines with larger undrawn rates, arguably those held by borrowers with lower liquidity needs.

A potential concern with these results is that not all of the cuts that we observe are bank driven. While we are unable to identify the driver of the credit line cut, we can

\footnotetext{
${ }^{9}$ An alternative interpretation for our findings is that borrowers' additional drawdowns trigger the cut. In this case, borrowers are still able to capitalize on their credit lines.

${ }^{10}$ Since the undrawn rates are computed as the ratio of the dollar amount that is still unused and the size of the credit line, we compute the post-cut rate as a function of the size of the credit line the borrower had beforehand. In this case, the cut reduces only the numerator of the undrawn rate.
} 
restrict our analysis to the subset of credit lines that are most likely to experience bank cuts i.e. credit lines that experience both a cut and an increase in drawdowns during the year. The average (median) undrawn rate for this subset of credit lines before the cut is $68 \%(72 \%)$. After the cut, these figures drop to $23 \%$ (16\%). By construction there is a bigger decline in undrawn rates following the cut, but once again we see relatively higher reductions in credit lines that had the highest undrawn rates (Figure 6, right graph). This too suggests that when banks cut credit lines they target borrowers with lower liquidity needs. Altogether, our evidence on credit line cuts is not consistent with the idea that banks effectively manage their credit lines to limit borrowers' ability to utilize them.

We investigate this hypothesis more closely using the following model of undrawn rates

$$
\begin{aligned}
& L U N D R A W N_{l, b, t}=c+\rho L U N D R A W N_{l, b, t-1}+\alpha C U T_{l, b, t} \\
& +\beta C U T_{l, b, t} \times L U N D R A W N_{l, b, t-1}+\beta X_{f, t-1}+\gamma Y_{l, t-1}+\eta Z_{b, t-1}+\zeta T_{t}+\epsilon_{l, b, t},
\end{aligned}
$$

where $L U N D R A W N_{l, b, t}$ is the log of one plus the undrawn rate in year t computed over the size of the credit line in year t-1). $C U T_{l, b, t}$ is dummy variable which takes the value one if the credit line experiences a cut in year t. We also consider a variant of this definition where we classify the credit line to experience a cut if its size declines and the borrower increases drawdowns over the same time period. $L U N D R A W N_{l, b, t-1}$ is the $\log$ of the undrawn rate in the credit line in year t-1 (also computed over the size of the credit line in year $\mathrm{t}-1)$.11

We consider a model of the log of undrawn rates because we want to confirm our previous finding suggesting that cuts disproportionaly impact credit lines with larger portions of undrawn funds. We estimate our model of undrawn rates controlling for

\footnotetext{
${ }^{11}$ We use the lagged size of the credit line to compute the undrawn rate in year $\mathrm{t}$ because otherwise a cut would mechanically increase the undrawn rate.
} 
our sets of loan-, borrower-, and bank specific factors as well as a set of year dummy variables. To highlight the bank-driven effects we also report the results we obtain when we estimate that model with bank-fixed effects and bank-year fixed effects.

The results of this investigation are reported in Table 4. They are consistent across all of the specifications we consider, including those that rely on the definition of cut that is most likely bank driven (Columns 4-6). As expected, cuts reduce undrawn rates: $C U T_{l, b, t}$ is always negative and statistically significant. The coefficient on the $\log$ of the lagged undrawn rate, $L U N D R A W N_{l, b, t-1}$, is positive and smaller than one across all specifications. Therefore, for credit lines that do not experience a cut the current undrawn rate increases less than proportionally with increases in their lagged undrawn rates. More importantly for our purposes, the coefficient on the interaction term is negative and significant. This shows that for credit lines with a cut, the current undrawn rates increases at an even slower rate with increases in their lagged undrawn rates when compared to credit lines that do not experience a cut. This is consistent with banks imposing larger cuts on credit lines with larger undrawn rates at the time of the cut 12 While cuts arguably reduce the liquidity insurance provided by credit lines, they are less costly had banks instead targeted credit lines that were already extensively utilized at the time of the cut.

\subsection{Managing the Credit Lines Rating}

We are able to do an alternative test to banks' ability to manage borrowers' drawdowns; one that speaks directly to the liquidity insurance credit lines offer borrowers. This insurance is likely most valuable in periods when borrowers experience financial difficulties because that is when it will be most difficult for them to find alternative sources of external funding. This assumes borrowers are able to drawdown their credit lines on

\footnotetext{
${ }^{12}$ The other possibility for this result is that borrowers with larger undrawn rates draw down larger amounts in the year they experience the cut on their credit line.
} 
these occasions. ${ }^{13}$ We investigate this hypothesis in this section by looking at borrowers' drawdowns ahead of banks downgrading the rating on their credit lines.

We rely on the lead bank's internal loan ratings to identify credit lines that are downgraded 14 We consider two alternative criteria to identify downgrades. The first criterion is broad and classifies downgrades as any change in the rating that points to a deterioration in the credit. The second criterion is narrower and classifies downgrades only when the portion of the credit rated PASS, the highest rating, declines. This is equivalent to a downgrade from investment grade to below grade. We identify 4,225 downgrades under the first criterion and 3,473 downgrades under the second one. We use the same approach to identify upgrades and find 2,177 and 1,349 upgrades under the two alternative criteria, respectively.

Figure 7 plots the drawdown rate on credit lines that experience a downgrade (left graph) and those that experience an upgrade (right graph) using our broad classification to identify rating changes ${ }^{15}$ There is a striking difference between the two graphs: there is no evidence of a change in borrowers' drawdown rates in the years leading up to an upgrade. In contrast, there is a sharp increase in borrowers' drawdown rates in the years leading up to a downgrade. The average drawdown rate on the year the credit line is downgraded is $59 \%$. The year before, the average drawdown rate on these credit lines was $41 \%$ and two years before it was only $36 \%$ In other words, in the two years leading up to the downgrade, borrowers are able to increase the drawdown rates on their credit lines by more than $50 \%$. Importantly, these effects are not driven by potential reductions in the size of the credit limes that may occur in the years leading up to the downgrade because we get similar results if we drop those credit lines from our sample.

\footnotetext{
${ }^{13}$ Banks could intervene and limit borrowers' drawdowns and in extreme cases even evoke the material adverse clause (MAC) that is common in credit line agreements and cancel the credit line. Berger and Udell (1995) note that banks are reluctant to evoke these clauses because of reputational concerns and fair lending laws.

${ }^{14}$ Banks rate credits into five continuous ratings: PASS, SPECIAL MENTION, SUBSTANDARD, DOUBTFULL and LOSS.

${ }^{15}$ Our results are similar when we use the narrower definition.
} 
We investigate borrowers' drawdown behavior around the time of the bank rating downgrade using the following model:

$$
C U T_{l, b, t}=c+\alpha_{i} \sum_{i=1} D G_{l, b, t-i}+\gamma Y_{l, t-1}+\eta Z_{b, t-1}+\psi T_{t}+\epsilon_{l, b, t}
$$

where $C U T$ is a dummy variable equal to one if the size of the credit line declines over the year t. In another specification we replace $C U T$ with $D R A W D O W N R A T E$, the percentage of the credit line the borrower has drawndown on its credit line. $D G_{l, b, t-i}$ is a set of dummy variables to isolate the years around the downgrade. We estimate these models controlling for our sets of loan- and bank-specific factors, $Y$, and $Z$, respectively, and yearly dummy variables, $T$. We do not use firm controls in this exercise because it reduces our sample significantly. However, in addition to reporting the results of a pooled analysis, we also estimate model (4) with loan-fixed effects and with loan- and bank-fixed effects.

The results of this investigation are reported in Table 5. The top panel reports the results for the likelihood of a reduction in the size of the credit line, CUT, while the bottom panel reports the results for the drawdown rate, DRAWDOWN RATE. Columns 1-3 in each panel report the results for our broad definition of rating downgrade while Columns 4-6 report the results for our narrow definition of downgrade. In addition, at the bottom of each column we report the p-value for the test that two consecutive dummy variables $D G_{l, b, t-i}$ are equal. An examination of the p-values for these tests reveals two important results. First, there is a clear increase in the likelihood of a reduction in the size of the credit line in the year of the downgrade (t) and the subsequent year $(\mathrm{t}+1)$. We can reject the hypotheses that $D G_{t+1}=D G_{t}$ and $D G_{t}=D G_{t-1}$ in all of our models. In contrast, we do not find evidence of an increase in the likelihood of a cut in the years leading up to a downgrade. We cannot reject the hypotheses that $D G_{t-1}=D G_{t-2}$ or $D G_{t-2}=D G_{t-3}$ in any of our models.

Second, in sharp contrast to this evidence on the likelihood of a reduction in the 
size of the credit line, we find strong evidence of an increase in drawdown rates in the years leading up to the downgrade. We can reject the hypothesis that $D G_{t-1}=D G_{t-2}$ in all of our models. There is even some evidence of an increase in drawdown rates from year (t-3) to year (t-2) because we can reject the hypothesis $D G_{t-2}=D G_{t-3}$ in four of our models. It is worth noting that these findings on drawdowns continue to hold when we drop all of the credit lines that experience a decline in their size during the sample period. This proves that the increase in drawdown rates derives from an increase in borrowers' utilization of their credit lines in the years leading up to a rating downgrade by their bank.

The sequencing we just documented provides strong evidence consistent with what we presented in Table 3 showing that borrowers' drawdowns precede credit line cuts. There is an important difference to the latest results: they build on a bank driven action - downgrade of its internal credit line rating. Regardless of borrowers' motivation behind this surge in drawdown rates, the fact that they are able to utilize their credit lines so extensively right before their bank downgrades them adds important support to the liquidity insurance role of these financial instruments.

Summing up, the results we reported in this section suggest that while credit lines may not be perfect substitutes for cash, they do provide liquidity insurance. Borrowers are able to increase drawdowns in recessions, arguably when they need funding the most. Further, their drawdowns tend to preceded credit line reductions, consistent with the idea that they are able to capitalize on their credit lines before banks intervene to cut their size. When banks cut credit lines they appear to target those with more unused funds, likely linked to borrowers with lower liquidity needs. In addition, on these occasions, banks still leave significant portions on undrawn funds in credit lines. Consistent with the previous assertion that borrowers are able to front run banks, our results show that borrowers significantly increase drawdowns on their credit lines before banks downgrade them and adjust their size downwards. 


\section{A Theory of Credit Line Syndicates}

In this section, we build on the previous evidence and develop a model where credit lines provide liquidity insurance. We assume (for reasons outside the model) that borrowers value liquidity insurance. We also assume that banks face higher liquidity provision costs during crisis (as, for example, in Rampini and Viswanathan (2019a) where there is a net worth shock to financial intermediaries). The model is intended to offer a better understanding of how incentive compatible syndicates are formed, and how syndicate shares are assigned, two important questions in understanding credit line syndicates that have not been considered in the prior literature. We pay particular attention to the incentive constraint for liquidity provision and the asymmetry between the lead bank and non-lead syndicate participants. We use the model to derive a set of empirical predictions which we test in the following section.

\subsection{The Borrower}

We consider a setup where a borrower wishes to obtain a credit line at variable interest rate $R>r$ where $r$ is the underlying benchmark rate for that risk class. Assume that the amount of the loan commitment is $L$ and the probability of a drawdown is $p$. Each credit line is assumed to be a one period commitment, so each credit line consists of a one time commitment fee, $C$, followed by an event whether the loan commitment is drawn or not (with probability $p$ ). The borrower needs a flat rate $R$ independent of any bank liquidity event; they are insured against any ex-post variations in bank liquidity costs. A loan commitment is a triple $(\mathrm{R}, \mathrm{C}, \mathrm{N})$ where: $\mathrm{C}$ is the commitment fee, $\mathrm{R}$ is the interest rate, and $\mathrm{N}$ is the number of banks in the syndicate. 


\subsection{Liquidity Events and Lenders}

Absent a liquidity event (which is an aggregate event), the cost of providing liquidity is $r$ and when liquidity events occur (which has probability $q$ ) the cost of providing funding of size $L$ is given by $r+m(L)$ where $m^{\prime}(L)>0$ and $m^{\prime \prime}(L)>0$ (strictly convex funding function). Also, we assume that $m(0)=0$ and $m^{\prime}(0)=0$. We assume that this liquidity event is systemic and is the same across all banks in the syndicate 16

Thus the syndicate receives a loan commitment fee $C$ and an interest $R$ if the loan commitment is exercised. It pays a normal cost of providing liquidity of $r$ and an additional cost of providing liquidity if a liquidity event occurs of $m\left(\frac{L}{N}\right) L$ if there are $N$ members in the syndicate and a cost of making the syndicate of $(N-1) x$ where $x$ is the incremental cost of adding a participant (these could represent coordination costs).

We are doing in a reduced form way what Holmstrom and Tirole (1997), Rampini and Viswanathan (2019b) and others have noted that ex post the interest rate on the commitment may be too low for it be incentive compatible. Holmstrom and Tirole (1997) focus on the incentive issue of delivering the loan commitment in the cross section and argue for a role for government bonds. Rampini and Viswanathan (2019b) focus on the general equilibrium and show that a collateral shortage in general equilibrium may reduce lending, increasing the cost today of a future loan commitment. Instead we focus on the institutional features of syndicates and the continuation value of the future firm relationship with syndicate members. We show that if that relationship has sufficient value, the syndicate will continue to make the loan commitment to the firm even when hit by liquidity shocks that increase the cost of supplying liquidity.

\footnotetext{
${ }^{16}$ It is clear that an idiosyncratic event that affects one bank does not matter; other banks can still provide liquidity at cost $r$. Only systemic events that affect all banks are relevant.
} 
Let $\Pi$ be the profit of the whole syndicate. Then it will be defined by

$$
\begin{aligned}
\Pi & =C+p R L-p(1-q) r L-p q\left(r+m\left(\frac{L}{N}\right)\right) L-(N-1) x \\
& =p(R-r) L+C-p q m\left(\frac{L}{N}\right) L-(N-1) x
\end{aligned}
$$

\subsection{Credit Lines with No Syndicate Ex Post Incentive Constraints}

We assume that the borrower has a profit function $\Pi^{B}(p(R-r) L, C)$ that is maximized at $(0,0)$, i.e. $\Pi^{B}(0,0)>\Pi^{B}(p(R-r) L, C)$ for all $C \geq 0$ and $R \geq r$. Further we assume that the partial derivatives satisfy $\Pi_{R}^{B}(p(R-r) L, C)<\Pi_{C}^{B}(p(R-r) L, C)=\Pi_{C}^{B}<0$ and $\Pi_{R R}^{B}(p(R-r) L, C)<0$. This implies that the borrower wishes to find $(R, C)$ that maximizes $\Pi^{B}(p(R-r) L, C)$ or equivalently

$$
\left[\Pi^{B}(0,0)-\Pi^{B}(p(R-r) L, C)\right]=H(p(R-r) L)+G(C)
$$

is a well defined convex cost function that can minimized with $H_{R}(p(R-r) L)>G_{C}>0$ and $H_{R R}(p(R-r) L)>0$ and $G_{C C}=0$.

Thus in a perfectly competitive market with no ex post constraints (first best) the maximization problem for the firm (or the equivalent cost minimization problem) is then given by

$$
\min _{R, C, N} H(p(R-r) L)+G(C)
$$

such that

$$
\begin{aligned}
& \left(\lambda_{F}\right)-p L(R-r)-C+p q m\left(\frac{L}{N}\right) L+(N-1) x \leq 0 \\
& (\mu)-R ; \leq-r \\
& (\gamma)-C ; \leq 0
\end{aligned}
$$


where the first constraint is the positive profit (breakeven) constraint on banks. The other two constraints require that the interest rate charged be greater than $r$ and that the loan commitment fee be positive.

Proposition 1 The first best syndicate size $N^{*}$ is determined by:

$$
-p q m^{\prime}\left(\frac{L}{N^{*}}\right) \frac{L^{2}}{\left(N^{*}\right)^{2}}+x=0
$$

which increases in $L$, the loan commitment size. Further, if $H_{R}(0)>G_{C}>0$, we have that $C>0$ and $R=r$; it is cheaper to put the cost of providing the first best loan commitment in the commitment fee rather than the interest rate and thus the interest rate will be $r{ }^{17}$ The first best commitment fee is:

$$
C=\operatorname{pqm}\left(\frac{L}{N^{*}}\right) L+\left(N^{*}-1\right) x
$$

The first best solution will not be ex post incentive compatible if a liquidity event occurs. When a liquidity event occurs, the marginal cost of providing liquidity is given by $r+m\left(\frac{L}{N}\right) \frac{L}{N}$, which must be less than the commtiment interest rate $R$. Ex post, the commitment fee is sunk. Hence, ex post incentive compatibility requires that

$$
R=r>r+m\left(\frac{L}{N}\right) \frac{L}{N}
$$

which is not true; thus, the credit line provides no liquidity insurance given the incentive constraint.

\subsection{The Syndicate Ex Post Incentive Constraint and Relationship Lending}

We now extend our model to consider the syndication process in a repeated game setting. As we will show, the repeated interaction of the syndicate with the firm can give rise to

\footnotetext{
${ }^{17}$ Implicit in searching for solutions where $R=r$ is the idea that the firm desires intertemporal insurance that is provided by the syndicate.
} 
the appropriate incentives.

Consider a stationary game (from Ray (2002), the self-enforcing contract must be stationary) Let $\Pi$ represent the static per period profit of the syndicate. Then, ex post, a syndicate member will provide the loan commitment if the ex post participation constraint holds

$$
R L+\frac{\delta \Pi}{1-\delta} \geq r L+m\left(\frac{L}{N}\right) L
$$

Equation (12) differs from Equation (13) by considering the discounted stream of profits that a syndicate member earns accounting for the decision to participate or not. The long run profit from being in the syndicate in the future (the relationship value) is enough to make the ex post participation constraint bind. Implicit in this approach is that a syndicate member who defects loses the long run profit and is not a member of the syndicate going forward (the outside option is zero) 18

This leads to the following condition for a stationary game:

$$
R \geq r+m\left(\frac{L}{N}\right)-\frac{\delta}{1-\delta} \frac{\Pi}{L}
$$

essentially, the interest rate charged has to be weakly greater than the marginal cost of financing minus the discounted long run profits earned by the syndicate. Thus, the syndicate has to make a positive profit when there are participation constraints, which implies the first best competitive equilibrium is not implementable. In the equilibrium, we construct (where $R=r$ ), the syndicate will earn a profit per period equal to $\frac{1-\delta}{\delta} m\left(\frac{L}{N}\right)$; the present value of these profits makes it incentive compatible for the syndicate to provide liquidity even when there are liquidity shocks to syndicates (events which occur over the life of the relationship with probability $p q$ ). Thus our construction has similarities to Board (2011) in that delaying the rents to the syndicate over the life of the relationship

\footnotetext{
${ }^{18}$ There could harsher punishments, the lead could remove a non-lead who defects and does not provide liquidity from all syndicates in which the non-lead participates with that lead.
} 
allows the firm to receive liqudity not just the first time the liquidity shock hits both firms and banks but for all such subsequent joint liquidity shocks ${ }^{19}$

\subsection{The Repeated Game}

Now, we formally consider the repeated game and solve for the second best loan commitment $\left(R_{t}, C_{t}, N_{t}\right)$ for all $t$. Following Ray $(2002)$, the optimal self enforcing contract that maximizes the firm payoffs must be stationary. Hence, we can write the firm's choice of contract given the ex post constraint on the bank as given by the problem:

$$
\min _{R, C, N} H(p(R-r) L)+G(C)
$$

such that

$$
\begin{gathered}
(\lambda)-(R-r) L \frac{1-(1-p) \delta}{1-\delta}-\frac{\delta}{1-\delta}\left[C-p q m\left(\frac{L}{N}\right) L-(N-1) x\right] \leq-m\left(\frac{L}{N}\right) L ; \\
(\mu) \\
(\gamma) \\
-C \leq-r ;
\end{gathered}
$$

Proposition 2 The optimal syndicate size is given by

$$
p q m^{\prime}\left(\frac{L}{N}\right) \frac{L^{2}}{N^{2}}+\frac{1-\delta}{\delta} m^{\prime}\left(\frac{L}{N}\right) \frac{L^{2}}{N^{2}}=x
$$

here $\hat{N}>N^{*}$ and as before $\hat{N}$ increases in $L$. If $\frac{H_{R}(0)}{G_{C}}>\frac{1-(1-p) \delta}{p \delta}>1, \hat{C}>C^{*}$ and $\hat{R}=r$.

Thus dynamic incentive issues lead to a higher syndicate size and higher commitment fees ${ }^{20}$ We can show the following comparative statics:

\footnotetext{
${ }^{19}$ We note that if switching between syndicates is allowed and the syndicate is allowed to make up front transfers to such a switching firm and if the switching cost $s$ exceeds $\frac{1-\delta}{\delta} m\left(\frac{L}{N}\right)$, no switching will occur. This is because if the firms switches today, then the new syndicate will conjecture that it will also switch tomorrow and thus a new syndicate will only pay the one period profit as rent which is insufficient to make to firm switch. As Board (2011) discusses in the context of franchise relationships, such up front payments are not common in practice.

${ }^{20}$ If the condition in Proposition 2 does not hold we get $\hat{R}>r$ and most likely $\hat{C}>C$.
} 
Proposition 3 Suppose either $p^{+}>p$ or $q^{+}>q$ or $\delta^{+}<\delta$, then $\hat{N}^{+}>\hat{N}$, the number of syndicate members goes up. Further $\hat{C}^{+}>\hat{C}$, the total commitment fees go up.

Essentially, a higher probability of drawdowns or a higher probability of bank stress or syndicates caring less for the future (for example, due to a crisis, banks are weaker and care less for future profits) must lead to larger syndicates and a higher commitment fee 21

\subsection{Syndicate Shares and Syndicate Profits}

In this subsection, we consider an extension where syndicate leads have greater ability to provide liquidity in a stressed state. In particular, we assume the following liquidity cost functions $m(L)$ and $n(L)$ for the lead and non-leads, respectively, are:

$$
\begin{array}{ll}
m(0)=n(0)=0 ; & m^{\prime}(0)=n^{\prime}(0)=0 \\
m^{\prime}(t)<n^{\prime}(t) ; \quad & m^{\prime \prime}(t)<n^{\prime \prime}(t) \quad \forall t>0
\end{array}
$$

Hence the lead bank has greater ability to provide insurance in a liquidity event than non-leads. Nevertheless, diversification is valuable and lead banks will share the liquidity risk with non-lead banks. Given a total loan size of $L$, let $L_{m}$ be the lead share and $L_{n}$ be the total non-lead share. Also, let $C_{m}$ be the commitment fee given the lead and $C_{n}$ be the total commitment fee given to the non-lead banks (and $C=C_{m}+C_{n}$ be the total commitment fee).

When we allow for the incentive constraint that both the lead and non-leads should have enough value from the relationship with the borrower for them not to walk

\footnotetext{
21 We are assuming in the model that $p$ is known and fixed. If we fix the syndicate size, we can allow for learning about $p$ from drawdowns since Equation 16 with $R=r$ implies a commitment fee that is linear in $p$ given fixed $N$; further Bayesian beliefs form a martingale. These two facts lead to a very similar dynamic model where $p$ is replaced by its expectation which changes over time. With an endogenous $N$, continuation utility is convex in $p$ given learning and need a more complicated set up. For the sake of brevity, we do not present these extensions.
} 
away from the loan commitment when liquidity shocks hit, we obtain that

$$
\begin{gathered}
R L_{m}+\frac{\delta^{L}}{1-\delta^{L}} \Pi_{L} \geq r L_{m}+m\left(L_{m}\right) L_{m} \\
R \frac{L_{n}}{N-1}+\frac{\delta^{N L}}{1-\delta^{N L}} \frac{\Pi_{N L}}{N-1} \geq r \frac{L_{n}}{N-1}+m\left(\frac{L_{n}}{N-1}\right) \frac{L_{n}}{N-1}
\end{gathered}
$$

where

$$
\begin{aligned}
\Pi_{L} & =p L_{m}(R-r)+C_{m}-p q m\left(L_{m}\right) L_{m}-(N-1) x, \\
\Pi_{N L} & =p L_{n}(R-r)+C_{n}-p q n\left(\frac{L_{n}}{N-1}\right) L_{n} .
\end{aligned}
$$

Let $d^{L}=\frac{\delta_{L}}{1-\delta_{L}}$ and $d^{N L}=\frac{\delta_{N L}}{1-\delta_{N L}}$. Then, the programming problem can be written as

$$
\min _{R, C, N, L_{n}} H(p(R-r) L)+G(C)
$$

such that

$$
\begin{aligned}
& \left(\lambda_{m}\right)-\left[1+p d^{L}\right] L_{m}(R-r)-d^{L}\left[C_{m}-p q m\left(L_{m}\right) L_{m}-(N-1) x\right]-m\left(L_{m}\right) L_{m} \leq 0 \\
& \left(\lambda_{n}\right)-\left[1+p d^{N L}\right] L_{n}(R-r)-d^{N L}\left[C_{n}-p q n\left(\frac{L_{n}}{N-1}\right) L_{n}\right]-n\left(\frac{L_{n}}{N-1}\right) L_{n} \leq 0 ; \\
& (\mu)-R \leq-r ; \\
& \left(\gamma_{n}\right)-C_{m} \leq 0 ; \\
& \left(\gamma_{n}\right)-C_{n} \leq 0 ;
\end{aligned}
$$

and we do not impose $L_{n} \geq 0$ as the first order conditions will ensure this.

The key comparative static that we focus on is what happens when $\Delta \delta^{N L}<0$ (the non-leads discount the future more). We can view this either as a failure by the non-leads on an existing syndicate (as we will see they will want to reduce their liquidity 
provision). Then for a given syndicate size, we are asking what is the lead's response to a failure by non-leads. Alternatively, we can view this as designing a new incentive compatible syndicate (we are allowing entry).

Proposition 4 Suppose $\delta^{L}>\delta^{N L}$ (and $d^{L}>d^{N L}$ ) and $R=r$. Suppose $n(t)=t^{\gamma}, \gamma>1$ and in a liquidity event $\Delta \delta^{N L}<0$ (the non-leads discount the future more), then the lead amount $L_{m}$ (for fixed syndicate size) and lead share $L_{m} / L$ (for a fixed loan size) have to go up. Further if we assume that $m(t)=t^{\psi}, \gamma>\psi>1$, given a fixed syndicate size the commitment fee to the lead $C_{m}$ and the total commitment fee $C_{m}+C_{n}$ increases. With a flexible syndicate size and with a fixed credit line size $L$, the condition $L_{m}<\psi L_{n}$ (the share of the lead is less than or not much bigger than the total share of the nonleads) suffices to obtain both an increase in $C_{m}$ (the lead fee) and an increase in total commitment fees $C_{m}+C_{n}$.

Proposition 4 shows that if non-leads have a liquidity shock that reduces their ability to credibly promise to provide liquidity in the future, the non-lead syndicate loan amount in total must fall and the lead's syndicate credit line size and fractional share must increase. If the lead share is not bigger than the total non-lead's share then for a fixed syndicate size the total loan amount must contract though the lead partially offsets the loss from the non-leads. If the loan size is fixed, then lead share and syndicate size must increase and the total commitment fees must go up. We consider these implications empirically next.

\section{Supporting Evidence for our Model's Predictions}

Our model generates several empirical implications. In this section we aim at testing five of these implications. The first implication is that supply shocks (as in recessions) increase credit lines' financing costs (Proposition 22) 22 Secondly, Proposition 3 implies

\footnotetext{
${ }^{22}$ This insight is not unique to our model; Rampini and Viswanathan 2019a) also suggest a similar effect of a supply shock.
} 
that a higher probability of drawdowns leads to higher commitment fees. If syndicates were to learn about the probability of drawdowns from past drawdowns (see footnote 21), then past drawdowns imply higher commitment fees. Further, our model has predictions on the endogenous number of syndicate members and the allocation of shares across syndicate members. Specifically, it predicts that larger credit lines should have larger syndicates (Proposition 2). Additionaly, it predicts that lead banks should retain a larger share of the credit lines they extend during crises periods (Proposition 4) ${ }^{23}$ Lastly, our model suggests that when syndicate member failure occurs, the lead bank will offset the decrease in the syndicate member credit amount partially but not completely (Proposition 4).

\subsection{Pricing of Credit Lines over the Business Cycle}

The first empirical implication of our model that we test is that the price banks charge to grant liquidity through credit lines increases in response to supply shocks akin to those we observe in recessions. The pricing structure of a credit line usually includes a commitment fee and a credit spread. The commitment fee compensates the bank for the liquidity risk it incurs by guaranteeing the firm access to funding at its discretion over the life of the credit line and up to the total commitment amount. In contrast, the credit spread compensates the bank for the credit risk it incurs when the borrower draws down on its credit line.

Given that borrowers' risk of failure and, as we saw in our investigation of drawdown rates, their liquidity needs tend to increase in downturns we would expect both commitment fees and credit spreads to increase in recessions. However, once we account for the drivers credit risk and liquidity risk as well as banks' costs of hedging these risks, our model suggests that supply shocks similar to recessions should have a larger impact

\footnotetext{
${ }^{23}$ We do not have data to compare the cost of a credit line with equivalent private lending. Schwert (2020) compares bank loans with equivalent public debt and argues that for non-investment grade firms the average premium over public debt is $1.4 \%$ to $1.7 \%$ or about half of the all-in-drawn spread.
} 
on credit lines' commitment fees than on their credit spreads (Proposition 2).

To test this hypothesis, we rely on Dealscan, the most comprehensive data source on syndicated loan prices, which reports information on undrawn fees and all-in-drawn spreads. The undrawn fee reflects the commitment fee, but it also includes other fees borrowers pay when they take out credit lines ${ }^{24}$ Similarly, the all-in-drawn spread, which is defined over Libor and equals the annual cost to a borrower for drawn funds, accounts for the credit spread but it also reflects other fees borrowers pay when they draw down their credit lines.

As documented in Figure 8, both undrawn fees and credit spreads tend to go up during recessions. This is particularly evident in the 2008/09 crisis. While both prices appear to move in tandem it is unclear from that figure their increases in recessions are comparable. To investigate this question we start by comparing their changes using a univariate analysis. The results of this analysis are reported in Table 7 . The top panel reports the results for undrawn fees while the bottom panel reports the results for all-indrawn spreads. In both panels Columns (1) and (4) report results of a pooled regression, while Columns (2) and (5) report the results estimate with borrower-fixed effects, and Columns (3) and (6) report results estimated with bank-borrower fixed effects.

According to the left-hand side columns in the top panel, on average undrawn fees increase by 6 bps during recessions, which corresponds to $21 \%$ of the mean undrawn fee (28 bps). The bottom panel shows that all-in-drawn spreads increase by $31-37$ bps during recessions, which corresponds to $20-24 \%$ of the sample mean (156 bps).

Looking at the right-hand models in both panels we see that, and consistent with Figure 8, the biggest impacts occured during the 2008/09 crisis. During this recession, undrawn fees increased by 13-15 bps, which corresponds to 46-54\% of the sample mean. All-in-drawn spreads, in turn, went up by 74-96 bps, which corresponds to $47-62 \%$ of the sample mean. As in the case of the average effects of recessions, we see that during

\footnotetext{
${ }^{24}$ Dealscan uses the wording all-in-undrawn spread when referring to the price firms pay on undrawn commitments, but in reality that price is not a spread because the fees are not markups over market interest rates.
} 
the 2008/09 recession the rise in undrawn fees is of "similar" magnitude to the rise in all-in-drawn spreads.

Of course these are based on univariate comparisons and do not account for the drivers of these prices. For that reason, we investigate banks' pricing of credit lines over the business cycle using the following pricing model:

$$
P R I C E_{f, l, b, t}=c+\alpha R E C E S S I O N_{t}+\beta X_{f, t-1}+\gamma Y_{l, t}+\eta Z_{b, t-1}+\epsilon_{f, l, b, t}
$$

where $P R I C E_{f, l, b, t}$ is either the undrawn fee or the all-in-drawn spread on credit line $l$ of firm $f$ from bank $b$ at issue date $t$. The key variable of interest in that specification is RECESSION, a dummy variable equal to 1 for the years that coincide with the three NBER recessions during our sample period. We also break down this dummy variable into three separate dummy variables, one for each of the three NBER recessions $(1990 / 91,2001$, and 2008/09) 25

We investigate the impact of recessions on banks' pricing of credit lines controlling for borrower-, loan- and arranger-specific factors, $X, Y$, and $Z$, respectively. These sets of controls are similar to those we used in our investigation of drawdown rates in Section 3.2, except for some differences resulting from differences between the SNC dataset which we used in that investigation and Dealscan which we use to investigate credit lines' prices. For example, Dealscan contains information on loan covenants and so we include here in our set of controls dummy variables to distinguish whether the borrower pledged collateral and whether it was subject to dividend restrictions. In addition, and following the relationship lending literature, we distinguish whether the borrower has a relationship with that bank by including a dummy variable equal to one if it also took the previous loan from that bank. As in our univariate analysis, we estimate our pricing model using a pooled regression, with borrower fixed effects, and with bank-borrower

\footnotetext{
${ }^{25}$ Given we have information on the origination date of each credit date, in this analysis we use information from NBER's peak and trough dates to identify the begining and the end of each recession.
} 
fixed effects.

The results of this investigation, reported in Table 8, depict a similar picture to the results of our univariate analysis but with somewhat smaller magnitudes. On average, during recessions undrawn fees go up by 2 to 3 bps, which corresponds to $7-11 \%$ of the sample mean. All-in-drawn spreads, in turn, increase by 6 bps, which corresponds to $4 \%$ of the sample mean. These results are driven by the 2008/09 recession. During this recession, undrawn fees went up by 6 bps (21\% of the mean) while all-in-drawn spreads increased by 15 to 25 bps (10 to $16 \%$ of the mean).

In total, our pricing results suggest that the effect of bank supply shocks are quite large in the 2008-2009 recession, consistent with Proposition 2. Further, and also consistent with Proposition 2, our results show that during recessions the increase in undrawn fees is higher than the increase in all-in-drawn spreads. The fact that this difference persists when we account for bank-borrower fixed effects, i.e. by comparing the pricing of credit lines from banks to the same borrowers in and out of recessions, adds impoortant support to that proposition.

\subsection{Drawdowns and the Pricing of Credit Lines}

The second implication that we test is whether borrowers which utilize their credit lines extensively pay higher commitment fees on their credit lines. We merge Dealscan, our source of undrawn fees, with SNC, our source of information on borrowers' drawdown rates, to investigate this hypothesis. Figure 9 plots the undrawn fees on new credit lines against their borrowers' one-year lagged drawdown rates. Clearly, firms that drawdown more in the past pay higher undrawn fees on their new credit lines. While at a $10 \%$ past drawdown rate the undrawn fees are around 30 basis points, at the a $90 \%$ past drawdown rate the undrawn fees are around 40 basis points. This is consistent with Proposition 3, to the extent that past drawdowns is in line with a higher probability of future drawdowns. 
To further test that proposition, we run a regression of the undrawn fees on new credit lines against the borrower's drawdowns in its oustanding credit line in the prior year. In another specification, we consider the drawdown rate two periods ago and the change in the drawdown rate from two periods ago to one period ago. This is ensure that we are not only capturing level effects. In both specifications, we control for the sets of borrower-, loan- and arranger-specific factors, $X, Y$, and $Z$, respectively, that we use in the previous section to investigate loan prices over the business cycle. Table 9 shows the results of this investigation. Columns (1)-(3) report results for the one-period lagged drawdown rates while Column (5)-(6) report results for the two-year lagged drawdown rates. Columns (1) and (4) show the results of a pooled analysis, while Columns (2) and (5) account for bank fixed effects. Columns (3) and (6) in turn show the results when we account for bank-firm fixed effects.

As we can see from Columns (1)-(3), borrowers with higher past (one year lagged) drawdown rates pay higher undrawn fees on their new credit lines. This association is robust. Note that the lagged drawdown rate is significant at a $1 \%$ even with bankfirm fixed effects (Column 3). According to that model, a one percent change in the drawdown rate leads to 4 basis point change in the fees; clearly the lagged drawdown rate matters. As Columns (4)-(6) show, this is not just a level effect: when we control for the drawdown rate two years ago, we see that borrowers who increase their credit line utilization from period -2 to period -1 pay higher undrawn fees on new credit lines

they take out in period 0 . To the extent that past drawdowns predict the probability of future drawdowns, this evidence is consistent with the insight from Proposition 3 that credit lines with a higher probability of drawdown carry carry higher commitment fees.

\subsection{Number of Investors in Credit Line Syndicates}

A key prediction of our model is that larger credit lines should have larger syndicates. We use the SNC database that we described in Section 2 to investigate this hypothesis 
because it allows us to control for the arranger's loan share, arguably an important factor in the number of investors the lead bank will be able to attract to the syndicate. Information on the lead bank's loan share is missing for the vast majority of the credits in Dealscan.

Figure 10 shows the scatter plot of the log of the number of investors in the syndicate and the log of the loan amount at origination. Based on the fitted line, there is a distinct positive correlation between the size of the syndicate and the size of the loan. A one-percent increase in the size of the loan translates into a 0.38 percent increase in the number of investors in the loan syndicate.

Of course that figure does not account for many other factors that likely explain the size of the syndicate for a credit line. To account for these factors, we estimate the following model:

$$
\begin{aligned}
\operatorname{LINVETORS}_{f, l, b, t} & =c+\alpha \operatorname{LAMOUNT} T_{f-t, b, t}+\beta X_{f, t-1}+\gamma Y_{l, t} \\
& +\eta Z_{b, t-1}+\psi T_{t}+\epsilon_{f, l, b, t}
\end{aligned}
$$

where LINVESTORS is the log of the number of syndicate participants at the time of the credit line origination. Our key variable of interest is LAMOUNT, the log of the loan amount. We investigate the relationship between these variables controlling for sets of borrower-, loan-, bank-specific factors, $X, Y$ and $Z$, respectively, that we used in our study of drawdown rates in Section 3.2. In addition, we include time fixed effects, $T$.

The results of this investigation are reported in Table 10. Column 1 reports the results of a pooled analysis while Column 2 adds bank fixed effects. Colum 3 in turn uses bank-firm fixed effects. Columns 4 through 6 repeat this analysis, but control additionally for the lead bank's loan share, $L E A D S H$.

As we can see from the six models, LAMOUNT is positive and highly statistically significant. Controlling for the lead bank's loan share reduces the size of the coefficient 
on $L A M O U N T$, but it does not alter its statistical significance. Interestingly, contrary to the idea that retaining a larger share of the loan helps the lead bank attract more investors to the syndicate, we find a negative relationship between the LINVESTORS and $L E A D S H$. Of course, it is possible this is driven by the endogeneity of $L E A D S H$. For example, arrangers may retain larger loan shares in riskier loans which also tend to have fewer investors in the syndicate. As for the economic magnitude, we see that a one-percent increase in the size of the loan leads to an increase in the number of investors that varies between $0.19 \%$ (Column 6) and $0.37 \%$ (Columns 1 and 2) ${ }^{26}$ These findings support to the result of Proposition 2 that larger credit lines should have larger syndicates because this increases the insurance capacity of the credit line.

\subsection{Lead Bank's Retained Loan Share}

Another specific prediction of our model pertains to the allocation of syndicate shares. In particular, a key insight from our theory of loan syndicates is that lead banks retain a larger share of the credit lines they arrange during crises periods (Proposition 4). As with the tests in Section (5.3) we test this hypothesis using data from the SNC database because it reports complete information syndicate participants' loan shares, including the lead bank.

Figure 11 plots the average loan share the lead bank retains at the time of origination for credit lines over the period 1988-2013. It shows a distinct v-shape over our sample period. Lead banks use to retain about $33 \%$ of the credit lines they originated in the late 1980s. Starting in 1989, this ratio began to decline reaching its minimum of $18 \%$ by 1999 . Since then this ratio has been trending up reaching $29 \%$ at the height of the 2008/09 crisis, and going further up to $31 \%$ by 2012.

According to Figure 11, there does not seem to exist an increase in the lead bank's

\footnotetext{
${ }^{26}$ We have done a similar analysis using data from Dealscan but without controlling for the lead bank's loan share. The results, which we report in the Internet Appendix Table A.2, confirm a strong positive correlation between the number of investors and the size of the loan with a higher economic effect - the estimated elasticity varies between 0.20 and 0.31 .
} 
loan share for the credit lines originated in the first two recessions during our sample period. However, it is clear that lead banks kept a larger share of the credit lines they originated during the 2008/09 crisis. We investigate the insight from our theory on lead banks' credit line shares formally using the following model:

$$
\operatorname{LEADSH}_{f, l, b, t}=c+\alpha \operatorname{RECESSION} N_{t}+\beta X_{f, t-1}+\gamma Y_{l, t}+\eta Z_{b, t-1}+\epsilon_{f, l, b, t},
$$

where $L E A D S H$, is the lead bank's loan share at the time of the credit line origination. As in our previous tests, we control for sets of loan-, borrower- and arranger-specific factors, which we believe could influence the lead banks' loan investment decision. The results of this investigation are reported in Table 11. Columns 1 through 3 use a single dummy variable to identify recessions while Columns 4 through 6 use separate dummy variables for each recession during our sample period. Columns 1 and 4 report the results of a pooled analysis while Columns 2 and 5 report the results estimated with bank fixed effects. Finally, models 3 and 6 report the results estimated with bank-firm fixed effects.

Looking at the first three columns we see that our RECESSION dummy variable is positive, but it is not statistically significant. Turning to the next set of columns, however, we see that indeed lead banks retained a larger share of the credit lines they originated during the 1990/91 and the 2008/09 recessions. These results hold both in our pooled model and when we use bank fixed effects, but not in the most restrictive specification estimated with bank-firm fixed effects. The latter was to be expected since only a reduced number of listed firms take out multiple credit lines from the same bank during the sample period ${ }^{27}$ According to Column 5, lead banks on average increased their loan share by five and two percentage points on the credit lines they originated during the 1990/91 and 2008/09 recessions, respectively, when compared to their loan shares on the credit lines they originated during good times. These results add support

\footnotetext{
${ }^{27}$ By design we opted for not including in our sample of new credit lines, renegotiations of existing credit lines. Doing so increases our sample size by about $17 \%$, but it does not affect our key findings, see Table IA. 3 in the Internet Appendix.
} 
to the key insight from our model (see Proposition 4) that lead shares should increase after recessions that result in changes in the long run survivability of syndicate members and the hence the ability of syndicate members to provide liquidity insurance.

\subsection{Liquidity Impact of a Syndicate Member Failure}

Perhaps the biggest risk to the liquidity insurance provided by credit lines is the risk of failure of a syndicate member. This is because in a credit line legal arrangement, each syndicate member commits only to its loan investment. As a result, the failure of a syndicate member will result in a reduction of the credit line and limits the borrower's drawdown ability, unless other banks step in and take on the investment of the failed bank. The theory we present (Proposition 4) suggests that reductions in non-lead's shares will only be partially offset by the lead bank. We test this empirical implication below using the lead bank response to the failure of a syndicate member.

We capitalize on the failure of 91 non-lead banks in our loan syndicates; these banks were present in 656 credit lines at the time of their failure ${ }^{28}$ Figure 12 plots the time series of those bank failures (left graph) and the number of credit lines in which they were present in the year they failed (right graph). As one would expect, bank failures cluster around recessions, in particular the recession of 1998/99 and that of 2008/09.

Figure 13, left graph, plots for the 522 credit lines in which a syndicate member bank fails, the percentage of them that experience a decline in the years around the failure year 29 As we can see from that graph, while in the year before the failure of the syndicate member, $15 \%$ of the credit lines experience a decline in their size, in the year of failure that percentage goes up to $32 \%$. Part of this increase is likely attributable to the bank failure, but it may also be driven by the increase in the incidence of credit

\footnotetext{
${ }^{28}$ We restrict this exercise to bank failures (including Bear Stern and Lehman Brothers) because we do not have a comprehensive database on nonbank failures. However, as noted above credit line syndicates are dominated by banks.

${ }^{29}$ We do not use in these graphs all of the 656 credit lines that experience a syndicate member failure because we drop those that were fully drawndown the year before the failure as well as those that we do not observe the year before the failure. We need the latter information to ascertain if there is a reduction in the credit line at the time of the failure.
} 
line cuts during recessions. Regardless of the rationale for that increase, $68 \%$ of the credit lines exposed to bank failures do not experience a cut in the year of failure. That percentage drops to $50 \%$ if we account for cuts in the year after the failure, which still leaves half of the credit lines unaffected by the failure.

This evidence suggests that credit lines are partially exposed to the risk of a syndicate member failure. This is partly due to the lead banks' response to the failure because they often increase their loan investments following the failure of a syndicate member bank (Figure 13, right graph). For example, while in the year before the failure, lead banks increase their investments in $16 \%$ of the credit lines, that percentage goes up to $25 \%$ in the year of failure. Further, lead banks' additional loan investments reduce the impact of the failure on the credit line. This is apparent in Figure 14, that plots the size of the credit line cut against the size of the investment the failed bank had in the credit line. While the size of the credit line cut is positively correlated with the investment the failed bank had in the credit line, the cut is always smaller when the lead bank increases its loan investment. Thus the lead arrangers' response does appear to reduce borrowers' liquidity risk associated with the failure of a syndicate member.

We take a closer look at these effects using the following model:

$$
\begin{gathered}
C U T_{l, b, t}=c+\rho L L E A D U_{l, b, t}+\alpha_{i} \sum_{i=1} F A I L_{l, b, t-i}+\beta_{i} \sum_{i=1} F A I L_{l, b, t-i} \times L L E A D U_{l, b, t-i} \\
+\gamma Y_{l, t-1}+\eta Z_{b, t-1}+\psi T_{t}+\epsilon_{l, b, t},
\end{gathered}
$$

where $C U T$ is a dummy variable equal to one if the size of the credit line declines over the year $t$. In another specification we replace $C U T$ with $L C U T$, the log of one plus the dollar amount reduction in the size of the credit line over the year $t$. FAIL is a set of dummy variables to isolate the years around the failure of the syndicate member. We use the year before the member failure as the control group. $L L E A D U$ is the log of one plus the additional dollar amount investment the lead bank makes on the credit line over the year. We estimate these models controlling for the sets of loan- and bank-specific factors 
that we use in Section in Section 3.2 as well as year dummy variables. Additionally, we control for the share of the credit line that used to be owned by the failed bank(s) and the share owned by the lead bank as well as the portion of the credit line that was still undrawn at the time of the failure. We do not use firm controls in this exercise because it reduces our sample significantly. However, in addition to reporting the results of a pooled analysis, we also estimate that model with loan fixed effects and with loan- and bank-fixed effects.

Table 12 reports the results of this investigation. Columns (1) through (3) report the results for the likelihood that the credit line experiences a cut over the year. Columns (4) through (6), in turn, report the results for the log of one plus the credit line cut. An examination of the results reveals two important findings. First, in the year of the failure the borrower is more likely to experience a reduction in the size of its credit line and to endure a larger reduction compared to the prior year (the control group). Note that FAILURE0, the dummy variable which isolates the year of failure, is positive and statistically significant across all models. Consistent with these effects being driven by the failure, we do not find evidence of reductions in the size of the credit line in the year after the failure (FAILURE1 is never statistically different from 0$)$.

Second, lead banks offer some, but only partial, insurance against that risk of failure of a syndicate member bank. Note that $L L E A D U$, the log of one plus the additional investment the lead arranger makes on the credit line over the year, and FAILURE $0 \times L L E A D U$ are both negative and statistically significant across all of our models. However, on close inspection we see that FAILURE0 + FAILURE $0 \times L L E A D U$ is always positive when computed at the mean of $L L E A D U$.

In other words, the failure of a syndicate member bank increases both the odds borrowers will experience a reduction in their credit lines and face larger reductions on their credit lines. However, lead banks often (but not always) respond by increasing their investments in credit lines, thereby reducing the adverse effect of the failure of 
syndicate member banks. This is consistent with Proposition 4 that suggests that leads will only partially offset the decline in credit triggered by non-leads' reduction in loan investments.

\section{Conclusion}

In this paper, we argue that credit lines represent commitments by syndicates and provide substantial liquidity insurance to borrowers. Empirically, we show that borrowers are able to increase significantly their draw downs during recessions, arguably when they need liquidity the most. While credit lines do experience cuts, these cuts tend to lag surges in drawdowns and occur at the end of recessions. Further, syndicates tend to target relatively less used credit lines and leave some slack for borrowers to draw down. Cuts can be bank or borrower driven, but in the case of internal bank rating downgrades we know that they are the result of a bank action. Importantly, we find that internal bank rating downgrades tend to lag a surge in borrowers' drawdown activity, suggesting that borrowers are able to obtain substantial credit before credit line cuts.

Building on that evidence, we provide a theory where supply shocks make liquidity provision difficult ex post but the long run value of the relationship provides benefits to syndicates supporting the credibility of credit line provision. Our theory predicts that credit lines with higher expected drawdown rates carry higher commitment fees, and larger credit lines have larger syndicates. It also predicts that both commitment fees and lead bank's retained loan shares are higher for credit lines issued during recessions. Last, reductions in non-lead's loan shares will only be partially offset by the lead bank and thereby affect the liquidity insurance role of credit lines. We find support for these predictions in the data. The evidence is particularly strong during the 2008-09 recession which had a large negative impact on the banking industry. In line with the last prediction of our theory, when a syndicate member bank fails we find that this does 
not always translate into a commensurate decline in the size of the credit line because the lead bank often steps in and increases its loan investment.

Taken together, our empirical evidence shows that credit lines are commitments and that firms receive substantial liquidity from credit lines, particularly during recessions when they need it the most. While bank syndicates do suffer supply shocks, syndicate leads who value their credit relationship with borrowers often step in to offset the lost credit line share. Overall, our results are supportive of Holmstrom and Tirole (1997) and Rampini and Viswanathan (2019b) insight that the credibility of credit lines is a critical aspect of liquidity provision. Our paper thus provides evidence supporting an ex ante view of credit lines - they are commitments that provide substantial liquidity, albeit imperfect. 
Figure 1: Credit line drawdowns during Covid-19 outbreak

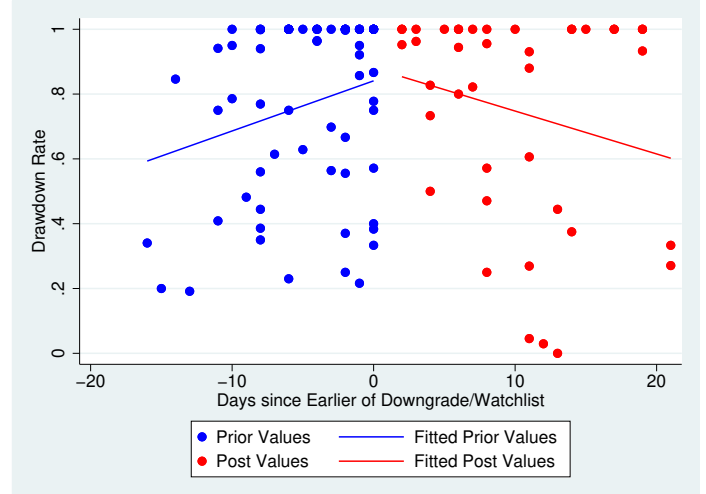

This figure plots drawdowns rates between March 12 and April 9, 2020 for corporations that experienced a credit rating downgrade or were put on a watch list by SP or Moody's' Source: LCD

Figure 2: New credit lines and term loans \& and banks' funding over time
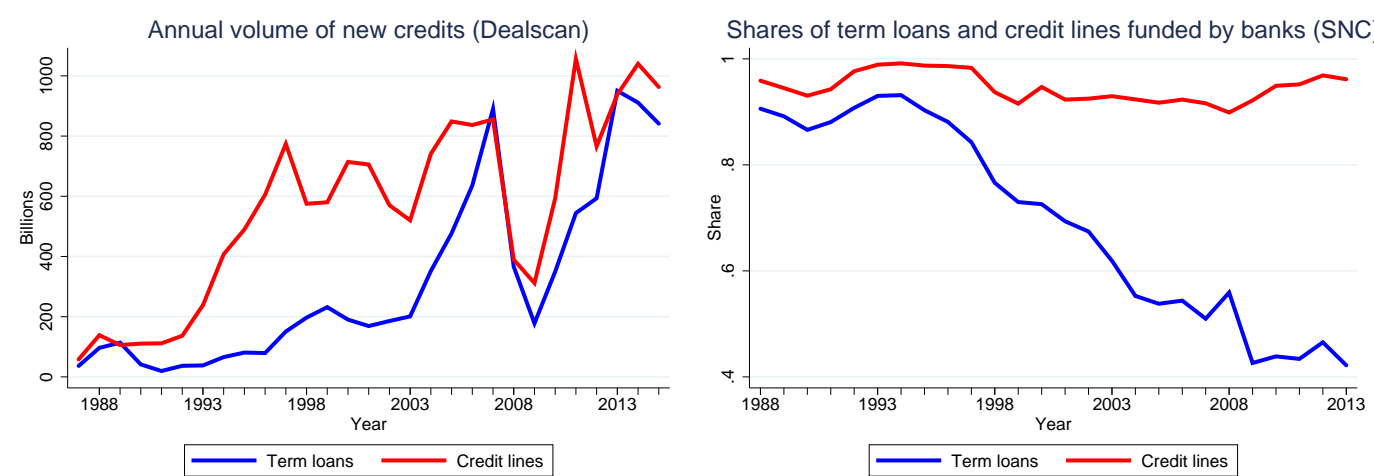

Left figure plots the time series of annual volumes of credit lines and term loans taken out by nonfinancial corporations.

Source: Dealscan. Right figure plots the time series of shares of credit lines and term loans taken out by nonfinancial corporations that are funded by banks. Source: SNC. 
Figure 3: Investor turnover in term loans and credit lines over time

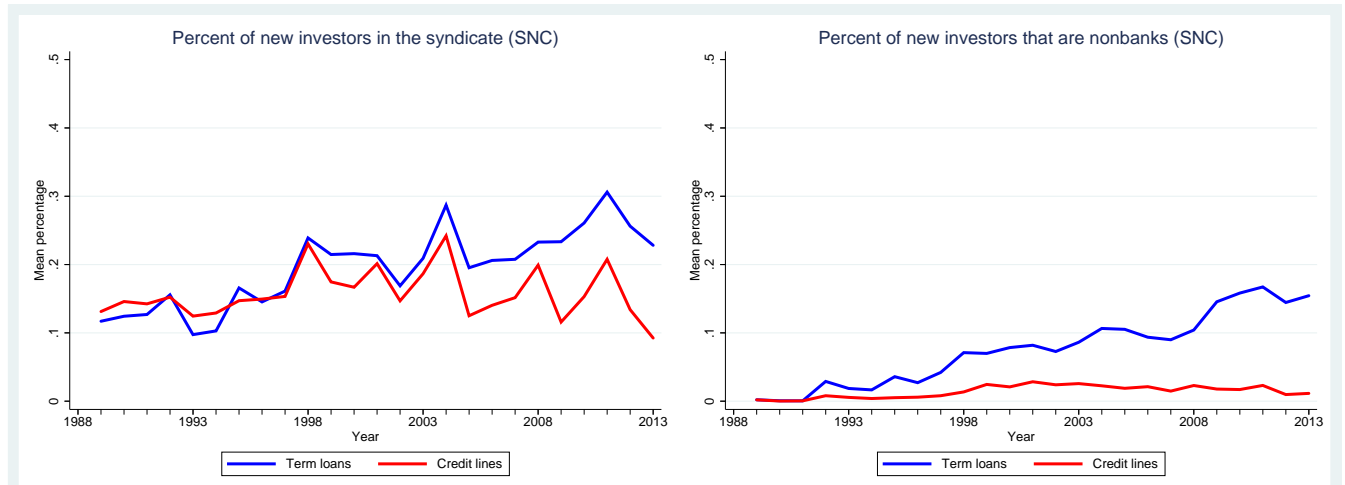

Left figure plots the mean annual percentage of new syndicate investors year over year. Right figure plots the mean percentage of new investors that are nonbanks. Source: SNC.

Figure 4: Drawdowns on credit lines over the business cycle
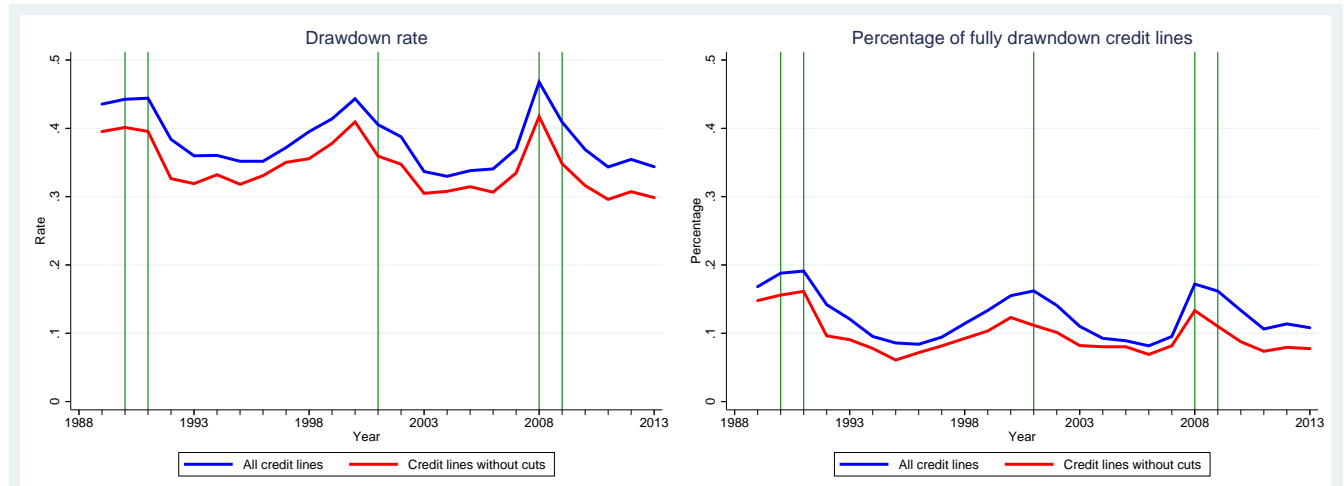

These figures plot the time series of the average annual drawdown rate and percentage of credit lines fully drawdown for all credit lines and for those whose commitment size does not change from one year to the next. Source: SNC

Figure 5: Drawdowns and credit line cuts over the business cycle

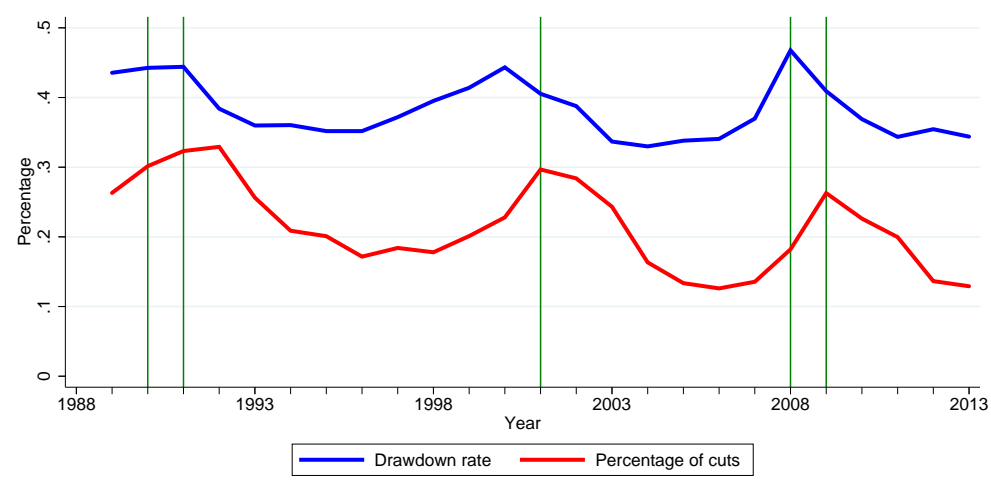

This figure plots the time series of the average annual drawdown rate and percentage of credit lines that experience a reduction in their size from one year to the next. Source: SNC 
Figure 6: Undrawn rates after the credit line cut by deciles of lagged undrawn rates

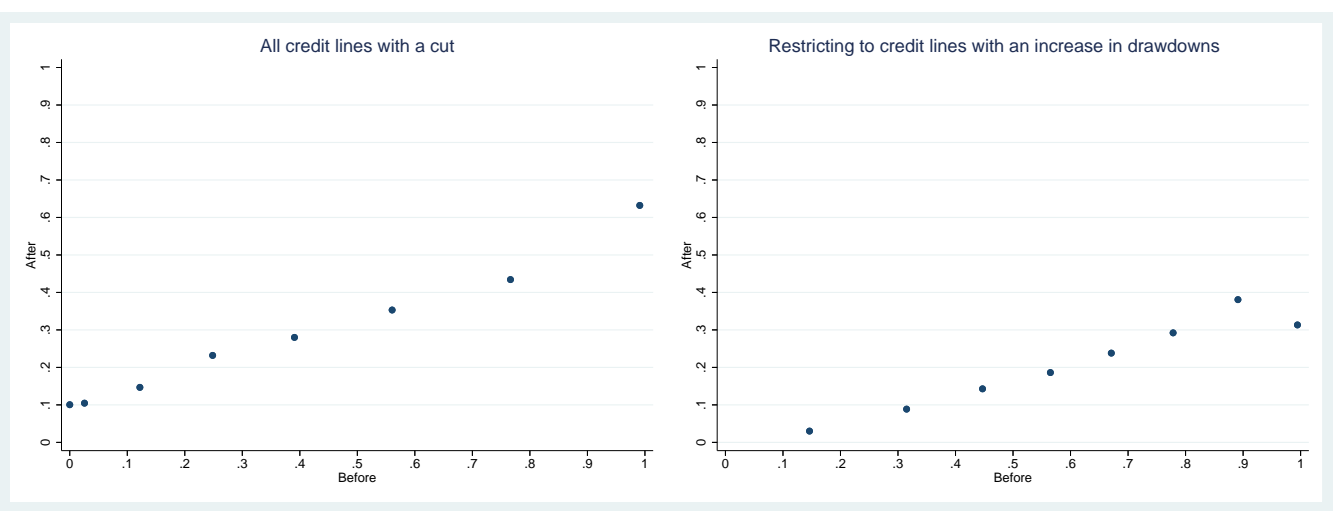

Left figure plots undrawn rates after credit lines experience a cut by deciles of undrawn rates prior to the cut. Right figure restricts the sample to credit lines that experience both a cut and an increase in the drawdown on the same year. Undrawn rates computed off the size of the credit line prior to the cut. Source: SNC

Figure 7: Drawdowns around downgrades and upgrades

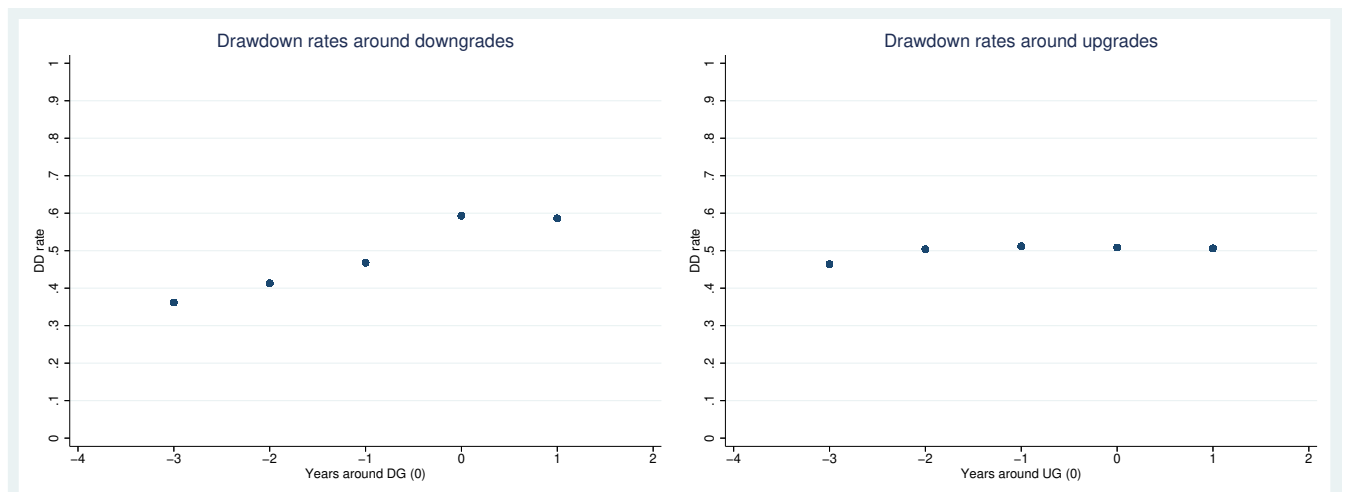

These figures plot the drawdown rates in credit lines that experience a downgrade (left figure) or an upgrade (right figure). Rating change occurs at year 0. Downgrades (upgrades) are determined by the lead bank and are defined as any rating change that are indicative of a deterioration (improvement) in the rating of the borrower. Source: SNC

Figure 8: Fees and spreads on credit lines over the business cycle

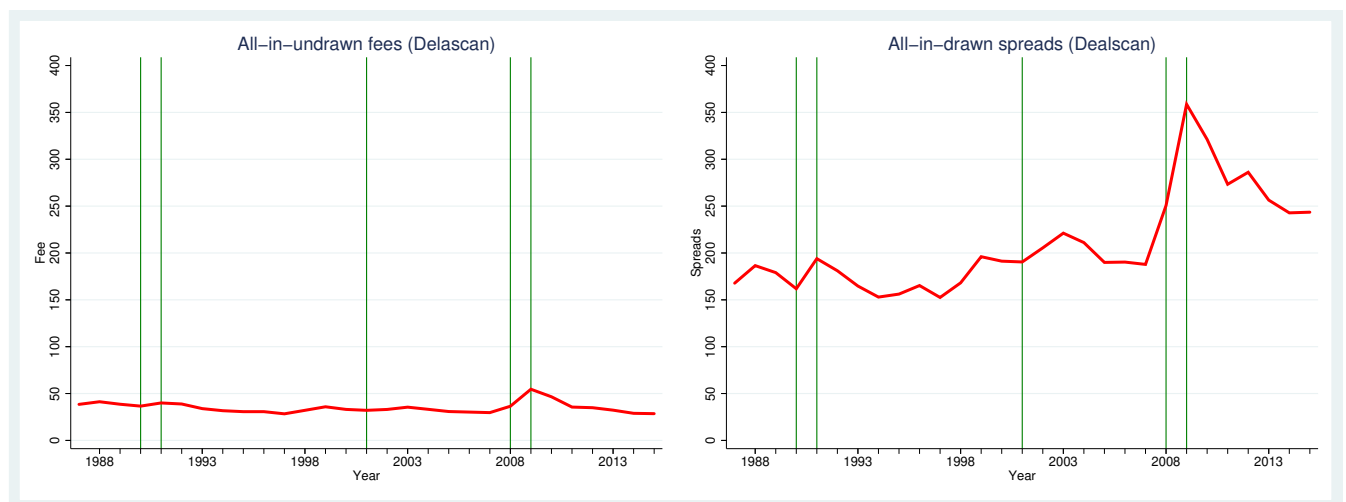

Left graph plots the annual average of undrawn fees on new credit lines over time. Right graph plots the annual average of all-in-drawn spreads over Libor on new credit lines over time. Source: Dealscan 
Figure 9: Past drawdowns and undrawn fees

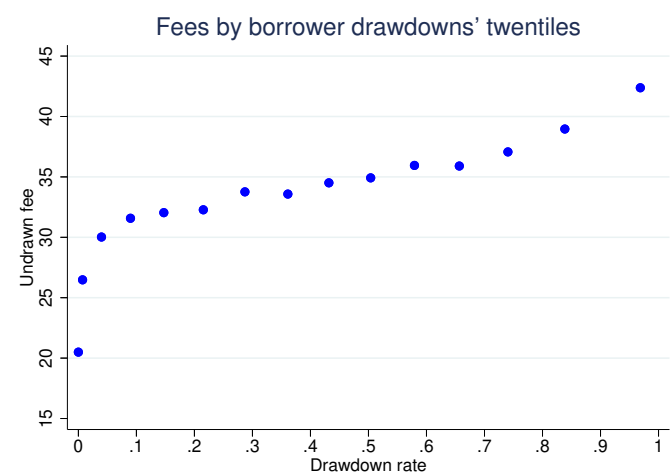

This figure plots undrawn fees against past drawdowns by the firm. Source: SNC, Dealscan

Figure 10: Number of investors and credit line size

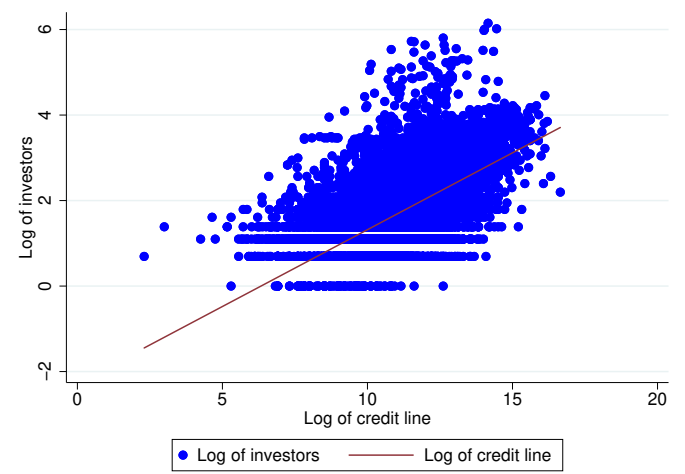

This figure plots the log of the number of investors and the credit line size at origination. Source: SNC

Figure 11: Lead bank loan share at origination over the business cycle

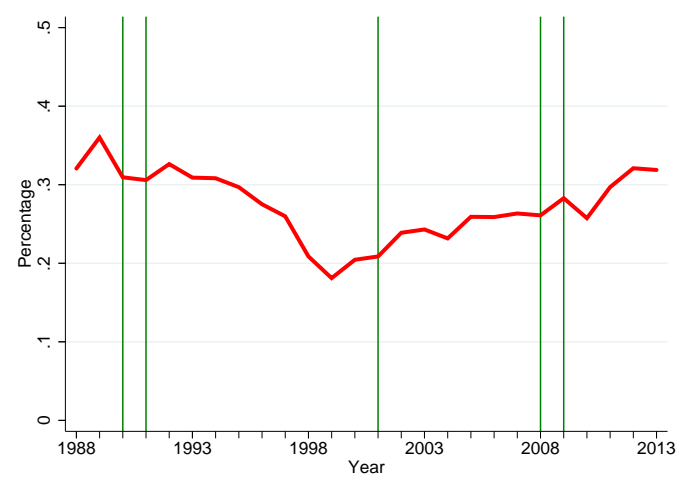

This figure plots the average arranger loan share at loan origination. Source: SNC 
Figure 12: Credit lines that experience a syndicate-member failure
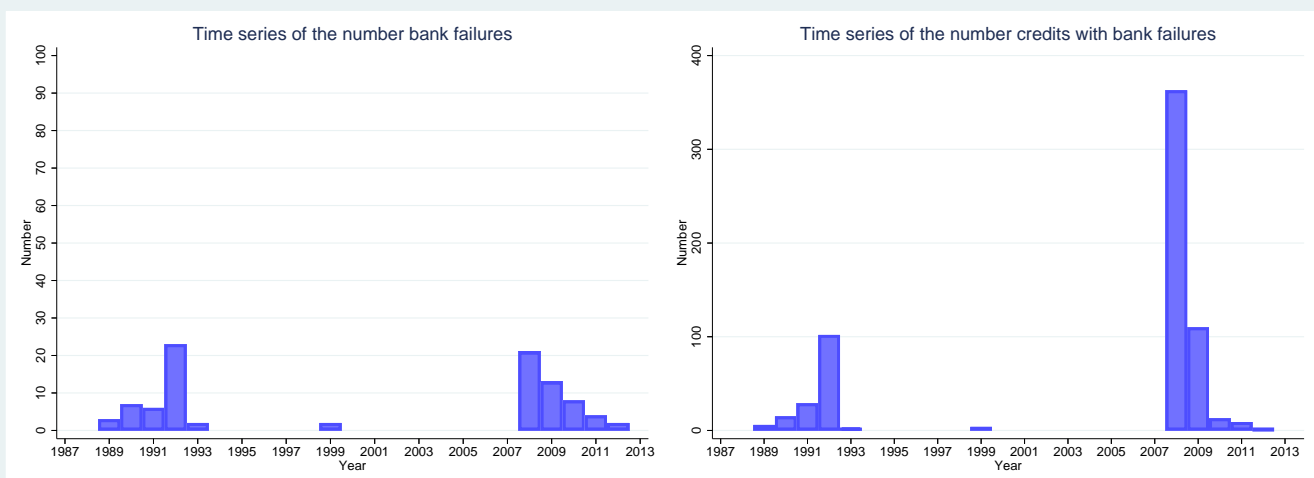

Left figure plots the time series of syndicate member failures (including Bear Sterns and Lehman Brothers). Source: FDIC Right figure plots the number of credit lines these banks were present at in the year they failed. Source: SNC

Figure 13: Incidence of cuts on credit lines when a syndicate-member fails
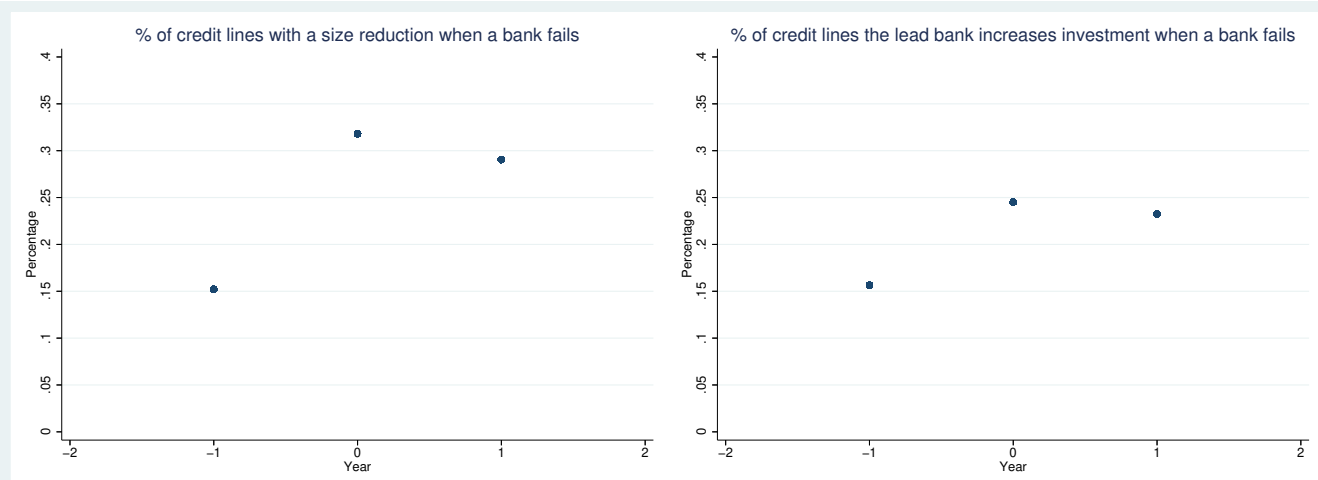

Left figure plots for the credit lines with the failure of a syndicate member bank, the percentage of them that experience a reduction in size around the year of failure (year 0). Right figure plots that same set of credit lines, the percentage of them that experience an increase in the lead arranger loan investment around the year of the syndicate member failure (year 0). Source: SNC

Figure 14: Credit line cuts when syndicate members fail

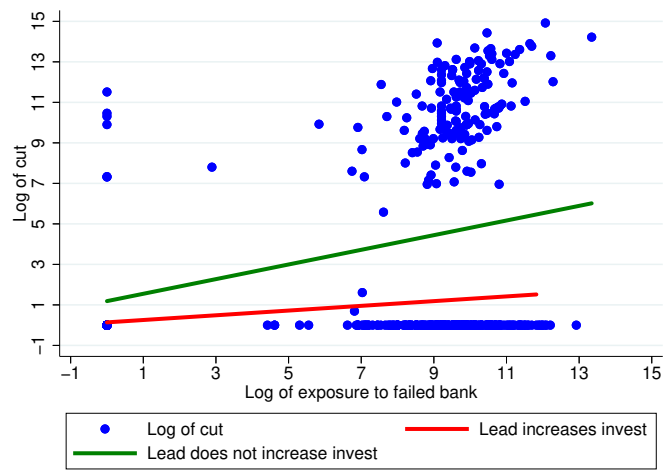

This graph plots the log of one plus the cut in credit lines on the year of the syndicate-member failure against the log of the loan investment that member bank held in the year prior to its failure. Fitted lines are for the credit line cuts when the lead bank increases and does not increase its loan investment in the year of failure, respectively. Source: SNC 
Table 1 Summary statistics for the credit lines in $\mathrm{SNC}^{a}$

\begin{tabular}{|c|c|c|c|c|c|c|c|c|c|}
\hline Variables & $\mathrm{N}$ & Mean & SD & 10th & 50 th & 90 th & Variables & $0 \%$ & $1 \%$ \\
\hline DRAWDOWN RATE & 109,592 & 0.38 & 0.37 & 0.00 & 0.30 & 1.00 & FULLY DRAWN & 87.43 & 12.57 \\
\hline UNDRAWN RATE & 109,592 & 0.62 & 0.37 & 0.01 & 0.70 & 1.00 & LOANIG & 11.58 & 88.42 \\
\hline $\operatorname{AMOUNT}(\$ M)$ & 109,592 & 222.9 & 474.3 & 20.0 & 90.0 & 500.0 & CPBCKUP & 96.19 & 3.81 \\
\hline MATURITYLEFT & 109,592 & 3 & 2.08 & 1 & 3 & 6 & WORKCAP & 52.03 & 47.97 \\
\hline LEADSH & 108,573 & 0.25 & 0.19 & 0.00 & 0.22 & 0.50 & $\mathrm{M} \& \mathrm{~A}$ & 91.78 & 8.22 \\
\hline \multirow[t]{4}{*}{ LENDERS } & 109,592 & 9 & 12.68 & 3 & 6 & 19 & RECAP & 98.36 & 1.64 \\
\hline & & & & & & & PROJFIN & 97.33 & 2.67 \\
\hline & & & & & & & CAPEXP & 98.07 & 1.93 \\
\hline & & & & & & & DEBT REPAY & 98.30 & 1.70 \\
\hline $\operatorname{ASSETSbk}(\$ B)$ & 95,530 & 527.44 & 679.53 & 28.15 & 186.93 & $1,822.07$ & & & \\
\hline CAPITALbk & 95,530 & 0.08 & 0.02 & 0.05 & 0.08 & 0.11 & & & \\
\hline ROAbk & 95,036 & 0.003 & 0.002 & 0.00 & 0.004 & 0.01 & & & \\
\hline LIQUITYbk & 95,275 & 0.07 & 0.04 & 0.03 & 0.06 & 0.12 & & & \\
\hline DEPOSITSbk & 94,431 & 0.58 & 0.15 & 0.40 & 0.60 & 0.75 & & & \\
\hline SALES(\$B) & 31,727 & 5.93 & 20.32 & 0.20 & 1.36 & 12.51 & AAA & 99.85 & 0.15 \\
\hline LEVERAGE & 31,380 & 0.33 & 0.19 & 0.09 & 0.31 & 0.57 & $\mathrm{AA}$ & 99.40 & 0.60 \\
\hline TANGIBLES & 32,363 & 0.68 & 0.42 & 0.09 & 0.70 & 0.99 & A & 96.14 & 3.86 \\
\hline PROFMARGIN & 31,686 & 0.04 & 0.13 & -0.05 & 0.04 & 0.15 & BBB & 93.53 & 6.47 \\
\hline LINTCOV & 26,294 & 2.01 & 0.92 & 1.04 & 1.90 & 3.16 & $\mathrm{BB}$ & 95.48 & 4.52 \\
\hline LIQUIDITY & 32,344 & 0.06 & 0.09 & 0.004 & 0.03 & 0.17 & B & 97.61 & 2.39 \\
\hline STOCKRET & 35,617 & 0.0003 & 0.002 & -0.002 & 0.0002 & 0.002 & $\mathrm{CCC}$ & 99.83 & 0.17 \\
\hline STOCKVOL & 35,613 & 0.001 & 0.002 & 0.0001 & 0.001 & 0.002 & & & \\
\hline
\end{tabular}

$a$ This table reports summary statistics for the credit lines in SNC data that we use in our paper. See Appendix B for the definitions of the variables. 
Table 2 Borrowers' drawdown on credit lines over the business cycle ${ }^{a}$

\begin{tabular}{|c|c|c|c|c|c|c|}
\hline \multicolumn{7}{|c|}{ Panel A: Drawdown rates: univariate analysis } \\
\hline Variables & 1 & 2 & 3 & 4 & 5 & 6 \\
\hline RECESSION & $\begin{array}{r}0.06^{* * *} \\
(5.13)\end{array}$ & $\begin{array}{r}0.06^{* * *} \\
(8.83)\end{array}$ & $\begin{array}{r}0.04^{* * *} \\
(6.26)\end{array}$ & & & \\
\hline RECESSION9091 & & & & $\begin{array}{r}0.08^{* * *} \\
(6.74)\end{array}$ & $\begin{array}{r}0.07 * * * \\
(6.53)\end{array}$ & $\begin{array}{r}0.04^{* * *} \\
(5.13)\end{array}$ \\
\hline RECESSION01 & & & & $\begin{array}{c}0.03^{*} \\
(1.74)\end{array}$ & $\begin{array}{r}0.04^{* * *} \\
(3.75)\end{array}$ & $\begin{array}{r}0.02^{* * * *} \\
(3.96)\end{array}$ \\
\hline RECESSION0809 & & & & $\begin{array}{r}0.06^{* * *} \\
(2.91)\end{array}$ & $\begin{array}{r}0.07 * * * \\
(5.61)\end{array}$ & $\begin{array}{r}0.05^{* * * *} \\
(3.70)\end{array}$ \\
\hline constant & $\begin{array}{r}0.37^{* * *} \\
(74.60)\end{array}$ & $\begin{array}{r}0.37^{* * *} \\
(131.59)\end{array}$ & $\begin{array}{c}0.37 * * * \\
(242.81)\end{array}$ & $\begin{array}{r}0.37^{* * *} \\
(74.60)\end{array}$ & $\begin{array}{r}0.37^{* * *} \\
(131.55)\end{array}$ & $\begin{array}{r}0.37^{* * *} * \\
(245.26)\end{array}$ \\
\hline Observations & 112086 & 112086 & 112086 & 112086 & 112086 & 112086 \\
\hline R-squared & 0.004 & 0.076 & 0.637 & 0.004 & 0.077 & 0.637 \\
\hline Bank FE & $\mathrm{NO}$ & YES & NO & NO & YES & NO \\
\hline Bank-Firm FE & NO & $\mathrm{NO}$ & YES & NO & NO & YES \\
\hline \multicolumn{7}{|c|}{ Panel B: Drawdown rates: multivariate analysis } \\
\hline Variables & 1 & 2 & 3 & 4 & 5 & 6 \\
\hline RECESSION & $\begin{array}{r}0.03^{* * *} \\
(3.34)\end{array}$ & $\begin{array}{r}0.03^{* * *} \\
(3.67)\end{array}$ & $\begin{array}{r}0.03^{* * *} \\
(3.74)\end{array}$ & & & \\
\hline RECESSION9091 & & & & $\begin{array}{r}0.02 \\
(1.34)\end{array}$ & $\begin{array}{r}0.02^{* *} \\
(2.02)\end{array}$ & $\begin{array}{r}0.02 \\
(1.05)\end{array}$ \\
\hline RECESSION01 & & & & $\begin{array}{r}-0.00 \\
(-0.10)\end{array}$ & $\begin{array}{r}-0.00 \\
(-0.38)\end{array}$ & $\begin{array}{r}0.00 \\
(0.24)\end{array}$ \\
\hline RECESSION0809 & & & & $\begin{array}{r}0.05^{* * *} \\
(4.40)\end{array}$ & $\begin{array}{r}0.05^{* * *} \\
(4.01)\end{array}$ & $\begin{array}{r}0.05^{* * * *} \\
(4.52)\end{array}$ \\
\hline constant & $\begin{array}{r}0.76^{* * *} \\
(11.82)\end{array}$ & $\begin{array}{r}0.44^{* * *} \\
(4.28)\end{array}$ & $\begin{array}{r}0.51^{* * *} \\
(3.24)\end{array}$ & $\begin{array}{r}0.79 * * * \\
(12.19)\end{array}$ & $\begin{array}{r}0.51^{* * *} \\
(4.97)\end{array}$ & $\begin{array}{r}0.59^{* * *} \\
(3.84)\end{array}$ \\
\hline Observations & 24293 & 24293 & 24293 & 24293 & 24293 & 24293 \\
\hline R-squared & 0.221 & 0.246 & 0.620 & 0.221 & 0.246 & 0.621 \\
\hline Bank FE & NO & YES & NO & NO & YES & NO \\
\hline Bank-Firm FE & NO & NO & YES & NO & NO & YES \\
\hline \multicolumn{7}{|c|}{ Panel C: Fully drawdown credit lines } \\
\hline Variables & 1 & 2 & 3 & 4 & 5 & 6 \\
\hline RECESSION & $\begin{array}{r}0.01^{* *} \\
(2.07)\end{array}$ & $\begin{array}{r}0.01^{* *} \\
(2.44)\end{array}$ & $\begin{array}{r}0.01^{* * *} \\
(2.98)\end{array}$ & & & \\
\hline RECESSION9091 & & & & $\begin{array}{r}0.03^{* *} \\
(2.12)\end{array}$ & $\begin{array}{r}0.02 \\
(1.48)\end{array}$ & $\begin{array}{r}0.01 \\
(0.41)\end{array}$ \\
\hline RECESSION01 & & & & $\begin{array}{r}-0.00 \\
(-0.45)\end{array}$ & $\begin{array}{r}0.00 \\
(0.44)\end{array}$ & $\begin{array}{r}0.00 \\
(0.39)\end{array}$ \\
\hline RECESSION0809 & & & & $\begin{array}{r}0.01^{*} \\
(1.67)\end{array}$ & $\begin{array}{r}0.01^{* *} \\
(2.19)\end{array}$ & $\begin{array}{r}0.02^{* * * *} \\
(4.63)\end{array}$ \\
\hline constant & $\begin{array}{r}0.64^{* * * *} \\
(9.88)\end{array}$ & $\begin{array}{r}0.36^{* * *} \\
(4.46)\end{array}$ & $\begin{array}{r}0.44^{* * *} \\
(3.68)\end{array}$ & $\begin{array}{r}0.64^{* * * *} \\
(9.81)\end{array}$ & $\begin{array}{r}0.37^{* * *} \\
(4.47)\end{array}$ & $\begin{array}{r}0.48^{* * *} \\
(4.03)\end{array}$ \\
\hline Observations & 24293 & 24293 & 24293 & 24293 & 24293 & 24293 \\
\hline R-squared & 0.079 & 0.110 & 0.496 & 0.079 & 0.110 & 0.496 \\
\hline Bank FE & $\mathrm{NO}$ & YES & $\mathrm{NO}$ & $\mathrm{NO}$ & YES & NO \\
\hline Bank-Firm FE & $\mathrm{NO}$ & $\mathrm{NO}$ & YES & $\mathrm{NO}$ & $\mathrm{NO}$ & YES \\
\hline
\end{tabular}

$a$ The dependent variable in Panels A and B is DRAWDOWN RATE, the drawdown rate on the credit line at the end of the year. The dependent variable in Panel $\mathrm{C}$ is $F U L L Y D R A W N$, a dummy variable equal to one if the credit line is fully drawndown (the borrower has drawdown at least $95 \%$ of the credit line). RECESSION is a dummy variable equal to one for the three recessions as classified by NBER during our sample period (1988-2013). RECESSION9091, RECESSION01 and RECESSION0809 are dummy variables for the recessions that occurred in 1990/91, 2001 and 2008/09, respectively. All of the models in Panels B and C include the sets of borrower-, loan-, and bank-specific factors reported in Table 1 as well as dummy variables to account for the borrower activity as defined by 1-digit SIC codes. Models estimated with robust standard errors clustered by bank and by firm. We report t statistics in parentheses. $* * *$ denotes $1 \%$ significant level, ** denotes $5 \%$ significant level, and $*$ denotes $10 \%$ significant level. 
Table 3 Borrowers' drawdowns and future credit line $\operatorname{cuts}^{a}$

\begin{tabular}{|c|c|c|c|c|c|c|}
\hline Variables & 1 & 2 & 3 & 4 & 5 & 6 \\
\hline$D R A W D O W N R A T E_{-1}$ & $\begin{array}{r}0.10^{* * *} \\
(8.22)\end{array}$ & $\begin{array}{r}0.06^{* * *} \\
(3.26)\end{array}$ & $\begin{array}{r}0.06^{* * *} \\
(3.80)\end{array}$ & & & \\
\hline$D R A W D O W N R A T E_{-2}$ & & & & $\begin{array}{r}0.09 * * * \\
(7.06)\end{array}$ & $\begin{array}{r}0.07 * * * \\
(3.02)\end{array}$ & $\begin{array}{r}0.07 * * * \\
(3.59)\end{array}$ \\
\hline$L D R A W A N A M T_{-1}$ & & & & $\begin{array}{r}0.00 \\
(1.15)\end{array}$ & $\begin{array}{r}0.00^{* *} \\
(2.14)\end{array}$ & $\begin{array}{r}0.00^{* *} \\
(2.46)\end{array}$ \\
\hline constant & $\begin{array}{r}0.41^{* * *} \\
(4.89)\end{array}$ & $\begin{array}{c}0.91^{*} \\
(1.81)\end{array}$ & $\begin{array}{r}0.74 \\
(1.49)\end{array}$ & $\begin{array}{r}0.44^{* * *} \\
(4.57)\end{array}$ & $\begin{array}{c}0.99^{*} \\
(1.70)\end{array}$ & $\begin{array}{r}0.95 \\
(1.62)\end{array}$ \\
\hline Observations & 16984 & 16984 & 15239 & 12328 & 12328 & 11027 \\
\hline R-squared & 0.081 & 0.434 & 0.358 & 0.078 & 0.445 & 0.368 \\
\hline Credit line FE & $\mathrm{NO}$ & YES & YES & $\mathrm{NO}$ & YES & YES \\
\hline Bank FE & $\mathrm{NO}$ & $\mathrm{NO}$ & YES & $\mathrm{NO}$ & NO & YES \\
\hline
\end{tabular}

a The dependent variable in this table is a dummy variable, which is equal to one in years when the credit line experiences a cut. DRAWDOWN RATE $E_{-1}$ and $D R A W D O W N R A T E_{-2}$ are the drawdown rates on credit lines at the end of year t-1 and t-2, respectively. $L D R A W N A M T_{-1}$ is the log of one plus the dollar amount the borrower draws done on its credit line during year t-1. All of the models include the sets of borrower-, loan-, and bank-specific factors reported in Table 1 as well as dummy variables to account for the borrower activity as defined by 1-digit SIC codes, and year dummy variables. Models estimated with robust standard errors clustered by credit line. We report t statistics in parentheses. *** denotes $1 \%$ significant level, ${ }^{* *}$ denotes $5 \%$ significant level, and $*$ denotes $10 \%$ significant level. 
Table 4: Avaliable funds after a credit line cut $^{a}$

\begin{tabular}{|c|c|c|c|c|c|c|}
\hline Variables & 1 & 2 & 3 & 4 & 5 & 6 \\
\hline$L U N D R A W N A M T_{-1}$ & $\begin{array}{r}0.55^{* * *} * \\
(23.18)\end{array}$ & $\begin{array}{r}0.53^{* * *} * \\
(22.04)\end{array}$ & $\begin{array}{r}0.54^{* * *} \\
(21.67)\end{array}$ & $\begin{array}{r}0.57^{* * *} \\
(27.45)\end{array}$ & $\begin{array}{r}0.56^{* * *} \\
(26.30)\end{array}$ & $\begin{array}{r}0.56^{* * *} \\
(25.90)\end{array}$ \\
\hline CUT & $\begin{array}{r}-0.11^{* * *} \\
(-7.88)\end{array}$ & $\begin{array}{r}-0.12^{* * *} \\
(-8.07)\end{array}$ & $\begin{array}{r}-0.11^{* * *} \\
(-7.59)\end{array}$ & & & \\
\hline$C U T \times L U N D R A W N A M T-1$ & $\begin{array}{r}-0.14^{* * *} \\
(-5.77)\end{array}$ & $\begin{array}{r}-0.14^{* * *} \\
(-5.58)\end{array}$ & $\begin{array}{r}-0.14^{* * *} \\
(-5.48)\end{array}$ & & & \\
\hline CUTn & & & & $\begin{array}{r}-0.19^{* * *} \\
(-8.09)\end{array}$ & $\begin{array}{r}-0.19^{* * *} \\
(-8.16)\end{array}$ & $\begin{array}{r}-0.20^{* * *} \\
(-7.77)\end{array}$ \\
\hline$C U T n \times L U N U S E D R A T_{-1}$ & & & & $\begin{array}{r}-0.16^{* * *} \\
(-3.30)\end{array}$ & $\begin{array}{r}-0.15^{* * *} \\
(-3.15)\end{array}$ & $\begin{array}{r}-0.13^{* * *} \\
(-2.61)\end{array}$ \\
\hline constant & $\begin{array}{r}0.01 \\
(0.12)\end{array}$ & $\begin{array}{r}0.10 \\
(0.56)\end{array}$ & $\begin{array}{r}0.04 \\
(1.44)\end{array}$ & $\begin{array}{r}-0.04 \\
(-0.72)\end{array}$ & $\begin{array}{r}0.05 \\
(0.29)\end{array}$ & $\begin{array}{r}-0.01 \\
(-0.20)\end{array}$ \\
\hline Observations & 16984 & 16984 & 16558 & 16984 & 16984 & 16558 \\
\hline R-squared & 0.324 & 0.333 & 0.364 & 0.303 & 0.311 & 0.342 \\
\hline Bank FE & $\mathrm{NO}$ & YES & $\mathrm{NO}$ & NO & YES & $\mathrm{NO}$ \\
\hline Bank-Year FE & $\mathrm{NO}$ & $\mathrm{NO}$ & YES & $\mathrm{NO}$ & $\mathrm{NO}$ & YES \\
\hline
\end{tabular}

a Dependent variable: Log of one plus the undrawn rate in the credit line computed the ratio of undrawn funds at the end of year t over the size of the credit line at year t-1. CUT : dummy variable equal to one if the credit line experiences a reduction in year t. CUTn : dummy variable equal to one if the credit line experiences a reduction in year $t$ and the borrower increases the amount drawdown during that same year. LUNUSEDRAT-1 : Log of one plus the undrawn rate in the credit line computed the ratio of undrawn funds at the end of year t-1 over the size of the credit line at year t-1. All of the models include the sets of borrower-, loan-, and bank-specific factors reported in Table 1 as well as dummy variables to account for the borrower activity as defined by 1-digit SIC codes, and year dummy variables. Models estimated with robust standard errors clustered by borrower and by bank. We report t statistics in parentheses. $* * *$ denotes $1 \%$ significant level, ** denotes $5 \%$ significant level, and ${ }^{*}$ denotes $10 \%$ significant level. 
Table 5: Cuts and drawdowns around bank downgrade of credit line's rating ${ }^{a}$

\begin{tabular}{|c|c|c|c|c|c|c|}
\hline \multicolumn{7}{|c|}{ Panel A: Likelihood of cut } \\
\hline Variables & 1 & 2 & 3 & 4 & 5 & 6 \\
\hline \multirow[t]{2}{*}{$D G_{+1}$} & $0.337^{* * *}$ & $0.243^{* * *}$ & $0.231^{* * *}$ & $0.296^{* * *}$ & $0.216^{* * *}$ & $0.201^{* * *}$ \\
\hline & $(27.74)$ & (8.99) & $(8.74)$ & $(22.71)$ & $(7.70)$ & $(7.30)$ \\
\hline \multirow[t]{2}{*}{ DG } & $0.289^{* * *}$ & $0.272^{* * *}$ & $0.265^{* * *}$ & $0.236^{* * *}$ & $0.243^{* * *}$ & $0.232^{* * *}$ \\
\hline & $(31.26)$ & $(10.54)$ & $(10.40)$ & $(23.61)$ & $(8.82)$ & $(8.51)$ \\
\hline \multirow{2}{*}{$D G_{-1}$} & $-0.021^{* * *}$ & 0.024 & 0.022 & $-0.017 * * *$ & 0.032 & 0.026 \\
\hline & $(-4.39)$ & $(1.10)$ & $(1.00)$ & $(-3.23)$ & $(1.45)$ & $(1.15)$ \\
\hline \multirow[t]{2}{*}{$D G_{-2}$} & $-0.013^{*}$ & 0.015 & 0.015 & $-0.015^{* *}$ & 0.016 & 0.013 \\
\hline & $(-1.80)$ & $(0.69)$ & $(0.69)$ & $(-2.09)$ & $(0.74)$ & $(0.57)$ \\
\hline \multirow[t]{2}{*}{$D G_{-3}$} & -0.010 & 0.021 & 0.023 & -0.005 & 0.027 & 0.026 \\
\hline & $(-1.80)$ & $(0.69)$ & $(0.69)$ & $(-0.53)$ & $(1.24)$ & $(1.20)$ \\
\hline \multirow[t]{2}{*}{ constant } & $0.206^{* * *}$ & $3.429 * * *$ & $4.100^{* * *}$ & $0.199 * * *$ & $3.482^{* * *}$ & $4.162^{* * *}$ \\
\hline & $(7.86)$ & $(15.57)$ & $(18.83)$ & $(7.56)$ & $(15.79)$ & $(19.04)$ \\
\hline Observations & 91263 & 68377 & 68366 & 91263 & 68377 & 68366 \\
\hline R-squared & 0.122 & 0.488 & 0.494 & 0.110 & 0.484 & 0.491 \\
\hline Credit line FE & NO & YES & YES & $\mathrm{NO}$ & YES & YES \\
\hline Bank FE & NO & $\mathrm{NO}$ & YES & $\mathrm{NO}$ & $\mathrm{NO}$ & YES \\
\hline \multicolumn{7}{|l|}{$\mathrm{p}$ value for $\mathrm{H} 0$ : } \\
\hline$D G_{+1}=\mathrm{DG}$ & 0.0004 & 0.0279 & 0.0127 & 0.0000 & 0.0672 & 0.0388 \\
\hline $\mathrm{DG}=D G_{-1}$ & 0.0000 & 0.0000 & 0.0000 & 0.0000 & 0.0000 & 0.0000 \\
\hline$D G_{-1}=D G_{-2}$ & 0.2506 & 0.3382 & 0.4773 & 0.7730 & 0.1038 & 0.1858 \\
\hline$D G_{-2}=D G_{-3}$ & 0.8128 & 0.6641 & 0.5209 & 0.3995 & 0.4178 & 0.3018 \\
\hline \multicolumn{7}{|c|}{ Panel B: Drawdown rate } \\
\hline Variables & 1 & 2 & 3 & 4 & 5 & 6 \\
\hline \multirow[t]{2}{*}{$D G_{+1}$} & $0.068^{* * *}$ & $0.114^{* * *}$ & $0.115^{* * *}$ & $0.061^{* * *}$ & $0.096^{* * *}$ & $0.101^{* * *}$ \\
\hline & $(7.26)$ & (5.10) & (5.14) & (6.29) & (4.15) & $(4.37)$ \\
\hline \multirow[t]{2}{*}{ DG } & $0.045^{* * *}$ & $0.090^{* * *}$ & $0.091^{* * *}$ & $0.033^{* * *}$ & $0.079^{* * *}$ & $0.084^{* * *}$ \\
\hline & $(5.80)$ & $(4.20)$ & $(4.22)$ & (4.07) & (3.48) & (3.69) \\
\hline \multirow[t]{2}{*}{$D G_{-1}$} & $0.083^{* * *}$ & $0.068^{* * *}$ & $0.069 * * *$ & $0.090^{* * *}$ & $0.065^{* * *}$ & $0.069^{* * *}$ \\
\hline & $(12.96)$ & $(3.46)$ & $(3.45)$ & $(12.82)$ & $(3.26)$ & $(3.41)$ \\
\hline \multirow[t]{2}{*}{$D G_{-2}$} & $0.037^{* * *}$ & 0.015 & 0.015 & $0.040^{* * *}$ & 0.011 & 0.013 \\
\hline & (4.03) & $(0.77)$ & $(0.75)$ & (4.35) & $(0.53)$ & $(0.65)$ \\
\hline \multirow[t]{2}{*}{$D G_{-3}$} & 0.015 & -0.004 & -0.004 & 0.016 & -0.005 & -0.002 \\
\hline & (1.19) & $(-0.19)$ & $(-0.18)$ & (1.26) & $(-0.26)$ & $(-0.12)$ \\
\hline \multirow[t]{2}{*}{ constant } & $1.012^{* * *}$ & $0.331^{* *}$ & $0.274^{*}$ & $1.008^{* * *}$ & $0.369^{* * *}$ & $0.315^{* *}$ \\
\hline & (26.33) & $(2.33)$ & $(1.78)$ & $(26.22)$ & $(2.60)$ & (2.06) \\
\hline Observations & 91263 & 68377 & 68366 & 91263 & 68377 & 68366 \\
\hline R-squared & 0.155 & 0.750 & 0.752 & 0.155 & 0.750 & 0.751 \\
\hline Credit line FE & $\mathrm{NO}$ & YES & YES & $\mathrm{NO}$ & YES & YES \\
\hline Bank FE & $\mathrm{NO}$ & $\mathrm{NO}$ & YES & $\mathrm{NO}$ & $\mathrm{NO}$ & YES \\
\hline $\mathrm{p}$ value for $\mathrm{H} 0$ : & & & & & & \\
\hline$D G_{+1}=\mathrm{DG}$ & 0.0035 & 0.0011 & 0.0009 & 0.0012 & 0.0366 & 0.0339 \\
\hline $\mathrm{DG}=D G_{-1}$ & 0.0000 & 0.0105 & 0.0096 & 0.0000 & 0.2330 & 0.1911 \\
\hline$D G_{-1}=D G_{-2}$ & 0.0000 & 0.0000 & 0.0000 & 0.0000 & 0.0000 & 0.0000 \\
\hline$D G_{-2}=D G_{-3}$ & 0.0595 & 0.0749 & 0.0800 & 0.0385 & 0.1478 & 0.1518 \\
\hline
\end{tabular}

a Dependent variable: Drawdown rate on the credit line at the end of the year. $D G_{+1}, D G_{,} D G_{-1}, D G_{-2}$ and $D G_{-3}$ are dummy variables equal to one for the year after, year of, year before, two years before, three years before the rating downgrade, respectively. Models 1 through 3 estimated for all rating downgrades. Models 4 through 6 estimated for downgrades from investment grade to below investment grade. All of the models in Panels A and B include the sets of loan-, and bank-specific factors reported in Table 1 as well as dummy variables to account for the borrower activity as defined by 1-digit SIC codes, and year dummy variables. Models estimated with robust standard errors clustered by the credit line. We report $t$ statistics in parentheses. *** denotes $1 \%$ significant level, ** denotes $5 \%$ significant level, and * denotes $10 \%$ significant level. 
Table 7 Cost of credit lines over the business cycle: Univariate results ${ }^{a}$

\begin{tabular}{|c|c|c|c|c|c|c|}
\hline \multicolumn{7}{|c|}{ Panel A: All-in-undrawn fees } \\
\hline Variables & 1 & 2 & 3 & 4 & 5 & 6 \\
\hline RECESSION & $\begin{array}{r}6.28^{* * *} \\
(4.37)\end{array}$ & $\begin{array}{r}6.32^{* * *} \\
(4.63)\end{array}$ & $\begin{array}{r}5.73^{* * *} \\
(4.08)\end{array}$ & & & \\
\hline RECESSION9091 & & & & $\begin{array}{r}8.52^{* * *} \\
(3.84)\end{array}$ & $\begin{array}{r}4.36^{* * *} \\
(2.76)\end{array}$ & $\begin{array}{r}0.57 \\
(0.28)\end{array}$ \\
\hline RECESSION01 & & & & $\begin{array}{l}-2.07^{*} \\
(-1.75)\end{array}$ & $\begin{array}{r}-1.13 \\
(-1.37)\end{array}$ & $\begin{array}{r}-0.08 \\
(-0.06)\end{array}$ \\
\hline RECESSION0809 & & & & $\begin{array}{r}14.82^{* * *} \\
(8.69)\end{array}$ & $\begin{array}{r}14.68^{* * *} \\
(9.26)\end{array}$ & $\begin{array}{r}13.17^{* * * *} \\
(9.00)\end{array}$ \\
\hline constant & $\begin{array}{r}27.14^{* * * *} \\
(26.08)\end{array}$ & $\begin{array}{r}27.13^{* * *} \\
(96.72)\end{array}$ & $\begin{array}{r}27.18^{* * *} \\
(236.75)\end{array}$ & $\begin{array}{r}27.14^{* * *} \\
(26.08)\end{array}$ & $\begin{array}{r}27.13^{* * *} \\
(101.46)\end{array}$ & $\begin{array}{r}27.17^{* * *} \\
(398.76)\end{array}$ \\
\hline Observations & 24305 & 24305 & 24305 & 24305 & 24305 & 24305 \\
\hline R-squared & 0.009 & 0.079 & 0.781 & 0.024 & 0.092 & 0.787 \\
\hline Borrower FE & NO & YES & NO & $\mathrm{NO}$ & $\mathrm{NO}$ & YES \\
\hline Bank-borrower FE & $\mathrm{NO}$ & $\mathrm{NO}$ & YES & $\mathrm{NO}$ & $\mathrm{NO}$ & YES \\
\hline Panel B: All-in-drav & spreads & & & & & \\
\hline & 1 & 2 & 3 & 4 & 5 & 6 \\
\hline RECESSION & $\begin{array}{r}36.96^{* * *} \\
(4.63)\end{array}$ & $\begin{array}{r}33.95^{* * *} \\
(4.49)\end{array}$ & $\begin{array}{r}30.87^{* * * *} \\
(4.27)\end{array}$ & & & \\
\hline RECESSION90/91 & & & & $\begin{array}{r}7.52 \\
(0.69)\end{array}$ & $\begin{array}{r}5.95 \\
(0.62)\end{array}$ & $\begin{array}{l}-13.19 \\
(-0.79)\end{array}$ \\
\hline RECESSION01 & & & & $\begin{array}{c}-10.44 \\
(-1.24)\end{array}$ & $\begin{array}{r}-7.66 \\
(-1.12)\end{array}$ & $\begin{array}{r}0.42 \\
(0.06)\end{array}$ \\
\hline RECESSION08/09 & & & & $\begin{array}{r}95.97^{* * *} \\
(10.98)\end{array}$ & $\begin{array}{r}85.80^{* * *} \\
(11.60)\end{array}$ & $\begin{array}{r}74.14^{* * * *} \\
(10.11)\end{array}$ \\
\hline constant & $\begin{array}{r}153.42^{* * * *} \\
(24.39)\end{array}$ & $\begin{array}{r}153.66^{* * *} \\
(120.26)\end{array}$ & $\begin{array}{r}153.90 * * * \\
(265.84)\end{array}$ & $\begin{array}{r}153.42^{* * *} \\
(24.38)\end{array}$ & $\begin{array}{r}153.67^{* * *} \\
(129.68)\end{array}$ & $\begin{array}{r}153.89^{* * *} \\
(460.51)\end{array}$ \\
\hline Observations & 27041 & 27041 & 27041 & 27041 & 27041 & 27041 \\
\hline R-squared & 0.009 & 0.115 & 0.773 & 0.027 & 0.129 & 0.778 \\
\hline Borrower FE & NO & YES & NO & NO & NO & YES \\
\hline Bank-borrower FE & $\mathrm{NO}$ & $\mathrm{NO}$ & YES & $\mathrm{NO}$ & $\mathrm{NO}$ & YES \\
\hline
\end{tabular}

a Dependent variable in Panel A is the undrawn fee borrowers pay when they take out a credit line. Dependent variable in Panel B is the All-in-drawn spread over Libor that borrowers pay on the funds they drawdown on their credit lines. $R E C E S S I O N$ is a dummy variable equal to one for the three recessions as classified by NBER during our sample period (1988-2013). RECESSION9091, RECESSION01 and RECESSION0809 are dummy variables for the recessions that occurred in 1990/91, 2001 and 2008/09, respectively. All of the models in Panels A and B include the sets of borrower-, loan-, and bank-specific factors reported in Table 1 as well as dummy variables to account for the borrower activity as defined by 1-digit SIC codes. In addition, we control for the triple-B over triple-A bond spread at the time of the credit line origination. Models estimated with robust standard errors clustered by borrower and by bank. We report t statistics in parentheses. $* * *$ denotes $1 \%$ significant level, $* *$ denotes $5 \%$ significant level, and $*$ denotes $10 \%$ significant level. 
Table 8 Cost of credit lines over the business cycle: Multivariate results ${ }^{a}$

\begin{tabular}{|c|c|c|c|c|c|c|}
\hline \multicolumn{7}{|c|}{ Panel A: All-in-undrawn fees } \\
\hline Variables & 1 & 2 & 3 & 4 & 5 & 6 \\
\hline RECESSION & $\begin{array}{r}2.53^{* * *} \\
(3.33)\end{array}$ & $\begin{array}{r}2.38^{* * *} \\
(3.41)\end{array}$ & $\begin{array}{r}2.28^{* * *} \\
(3.04)\end{array}$ & & & \\
\hline RECESSION9091 & & & & $\begin{array}{r}1.63 \\
(1.20)\end{array}$ & $\begin{array}{r}0.91 \\
(0.75)\end{array}$ & $\begin{array}{r}-0.01 \\
(-0.00)\end{array}$ \\
\hline RECESSION01 & & & & $\begin{array}{r}-0.57 \\
(-0.69)\end{array}$ & $\begin{array}{r}-0.33 \\
(-0.42)\end{array}$ & $\begin{array}{r}-0.57 \\
(-0.82)\end{array}$ \\
\hline RECESSION0809 & & & & $\begin{array}{r}6.21^{* * *} \\
(4.94)\end{array}$ & $\begin{array}{r}5.82^{* * *} \\
(5.05)\end{array}$ & $\begin{array}{r}6.25^{* * *} \\
(5.24)\end{array}$ \\
\hline constant & $\begin{array}{r}12.96^{* *} \\
(2.00)\end{array}$ & $\begin{array}{r}-0.46 \\
(-0.06)\end{array}$ & $\begin{array}{r}-4.58 \\
(-0.62)\end{array}$ & $\begin{array}{r}13.52^{* *} \\
(2.11)\end{array}$ & $\begin{array}{r}1.65 \\
(0.20)\end{array}$ & $\begin{array}{r}-1.53 \\
(-0.21)\end{array}$ \\
\hline Observations & 24305 & 24305 & 24305 & 24305 & 24305 & 24305 \\
\hline R-squared & 0.546 & 0.560 & 0.841 & 0.548 & 0.561 & 0.842 \\
\hline Borrower FE & $\mathrm{NO}$ & YES & $\mathrm{NO}$ & $\mathrm{NO}$ & $\mathrm{NO}$ & YES \\
\hline Bank-borrower FE & $\mathrm{NO}$ & $\mathrm{NO}$ & YES & $\mathrm{NO}$ & $\mathrm{NO}$ & YES \\
\hline Panel B: All-in-drav & preads & & & & & \\
\hline & 1 & 2 & 3 & 4 & 5 & 6 \\
\hline RECESSION & $\begin{array}{l}6.43^{*} \\
(1.77)\end{array}$ & $\begin{array}{r}2.82 \\
(0.93)\end{array}$ & $\begin{array}{r}6.34^{* *} \\
(2.17)\end{array}$ & & & \\
\hline RECESSION9091 & & & & $\begin{array}{r}-18.12^{* *} \\
(-2.17)\end{array}$ & $\begin{array}{r}-5.69 \\
(-0.62)\end{array}$ & $\begin{array}{l}-18.60 \\
(-0.95)\end{array}$ \\
\hline RECESSION01 & & & & $\begin{array}{r}-4.49 \\
(-1.00)\end{array}$ & $\begin{array}{r}-5.76 \\
(-1.38)\end{array}$ & $\begin{array}{r}-2.30 \\
(-0.67)\end{array}$ \\
\hline RECESSION0809 & & & & $\begin{array}{r}24.83^{* * * *} \\
(3.20)\end{array}$ & $\begin{array}{r}15.04^{* *} \\
(2.26)\end{array}$ & $\begin{array}{r}21.87^{* * *} * \\
(3.86)\end{array}$ \\
\hline constant & $\begin{array}{r}-7.09 \\
(-0.11)\end{array}$ & $\begin{array}{r}-231.63^{* * *} \\
(-2.93)\end{array}$ & $\begin{array}{r}-417.97 * * * \\
(-8.89)\end{array}$ & $\begin{array}{r}-1.84 \\
(-0.03)\end{array}$ & $\begin{array}{r}-223.15^{* * *} \\
(-2.82)\end{array}$ & $\begin{array}{r}-403.47^{* * *} \\
(-8.66)\end{array}$ \\
\hline Observations & 27041 & 27041 & 27041 & 27041 & 27041 & 27041 \\
\hline R-squared & 0.577 & 0.611 & 0.860 & 0.579 & 0.611 & 0.860 \\
\hline Borrower FE & NO & YES & NO & NO & NO & YES \\
\hline Bank-borrower FE & $\mathrm{NO}$ & NO & YES & $\mathrm{NO}$ & $\mathrm{NO}$ & YES \\
\hline
\end{tabular}

a Dependent variable in Panel A is the All-in-undrawn fees borrowers pay when they take out a credit line. Dependent variable in Panel B is the All-in-drawn spread over Libor that borrowers pay on the funds they drawdown on their credit lines. RECESSION is a dummy variable equal to one for the three recessions as classified by NBER during our sample period (1988-2013). RECESSION9091, RECESSION01 and RECESSION0809 are dummy variables for the recessions that occurred in 1990/91, 2001 and 2008/09, respectively. All of the models in Panels A and B include the sets of borrower-, loan-, and bank-specific factors reported in Table 1 as well as dummy variables to account for the borrower activity as defined by 1-digit SIC codes. In addition, we control for the triple-B over triple-A bond spread at the time of the credit line origination. Models estimated with robust standard errors clustered by borrower and by bank. We report t statistics in parentheses. $* * *$ denotes $1 \%$ significant level, $* *$ denotes $5 \%$ significant level, and $*$ denotes $10 \%$ significant level. 
Table 9 Undrawn fees versus borrowers' drawdowns ${ }^{a}$

\begin{tabular}{lrrrrrr}
\hline \hline Variables & 1 & \multicolumn{1}{c}{3} & \multicolumn{1}{c}{3} & 4 & 5 & \multicolumn{1}{c}{} \\
\hline DRAWDOWN1 & $1.96^{* * *}$ & $1.98^{* * *}$ & $3.86^{* * *}$ & & & \\
DRAWDOWN2 & $(2.88)$ & $(2.97)$ & $(3.91)$ & & & \\
& & & & $2.54^{* * *}$ & $2.57^{* * *}$ & $3.67^{* *}$ \\
$\delta$ DRAWDOWN & & & & $(3.28)$ & $(3.41)$ & $(2.35)$ \\
& & & & $1.45^{* *}$ & $1.39^{* *}$ & $3.24^{* * *}$ \\
& & & & $(2.08)$ & $(2.01)$ & $(3.34)$ \\
\hline constant & $25.77^{* * *}$ & $16.90^{* *}$ & $44.53^{* * *}$ & $33.14^{* * *}$ & $24.64^{* * *}$ & $37.85^{* * *}$ \\
& $(4.42)$ & $(2.41)$ & $(4.30)$ & $(7.40)$ & $(3.25)$ & $(2.82)$ \\
Observations & 16841 & 16841 & 16841 & 15135 & 15135 & 15135 \\
R-squared & 0.642 & 0.649 & 0.867 & 0.648 & 0.654 & 0.873 \\
Bank FE & NO & YES & NO & NO & YES & NO \\
Bank-Firm FE & NO & NO & YES & NO & NO & YES \\
\hline \hline
\end{tabular}

${ }^{a}$ The dependent variable is the undrawn fee on the credit line. DRAWDOWN1 (DRAWDOWN2) year-end drawdown rate in the credit line the borrower has outstanding the year (two years) before the origination of the new credit line. $\delta D R A W D O W N=D R A W D O W N 1-D R A W D O W N 2$. All of the models include the sets of loan-, and bank-specific factors reported in Table 1 as well as dummy variables to account for the borrower activity as defined by 1-digit SIC codes. In addition, we control for the triple-B over triple-A bond spread at the time of the credit line origination. Models estimated with robust standard errors clustered by bank and by firm. We report t statistics in parentheses. ${ }^{* * *}$ denotes $1 \%$ significant level, ${ }^{* *}$ denotes $5 \%$ significant level, and ${ }^{*}$ denotes $10 \%$ significant level. 
Table 10 Number of loan investors and loan size ${ }^{a}$

\begin{tabular}{lrrrrrr}
\hline \hline Variables & \multicolumn{1}{c}{2} & \multicolumn{1}{c}{3} & \multicolumn{1}{c}{4} & \multicolumn{1}{c}{5} & \multicolumn{1}{c}{6} \\
\hline LAMOUNT & $0.37^{* * *}$ & $0.37^{* * *}$ & $0.26^{* * *}$ & $0.28^{* * *}$ & $0.27^{* * *}$ & $0.19^{* * *}$ \\
& $(28.92)$ & $(29.14)$ & $(4.75)$ & $(24.56)$ & $(23.75)$ & $(4.92)$ \\
LEADSH & & & & $-1.87^{* * *}$ & $-2.20^{* * *}$ & $-2.39^{* * *}$ \\
& & & & $(-27.85)$ & $(-29.42)$ & $(-5.13)$ \\
\hline constant & $-2.93^{* * *}$ & $-2.69^{* * *}$ & $-4.69^{*}$ & $-0.63^{* * *}$ & -0.09 & -0.18 \\
& $(-11.86)$ & $(-4.01)$ & $(-1.70)$ & $(-2.73)$ & $(-0.14)$ & $(-0.09)$ \\
Observations & 4852 & 4852 & 4852 & 4830 & 4830 & 4830 \\
R-squared & 0.621 & 0.652 & 0.957 & 0.741 & 0.774 & 0.971 \\
Bank FE & NO & YES & NO & NO & YES & NO \\
Bank-Firm FE & NO & NO & YES & NO & NO & YES \\
\hline \hline
\end{tabular}

a The dependent variable in this table is the log of the number of investors in the syndicate at the time of the loan origination. LAMOUNT is the log amount of the credit line. LEADSH is the share of the credit line the lead bank retains. All of the models in Panels A and B include the sets of borrower-, loan-, and bank-specific factors reported in Table 1 as well as dummy variables to account for the borrower activity as defined by 1-digit SIC codes, and year dummy variables. Models estimated with robust standard errors clustered by bank and by firm. We report t statistics in parentheses. $* * *$ denotes $1 \%$ significant level, ** denotes $5 \%$ significant level, and * denotes $10 \%$ significant level. 
Table 11 Lead bank's loan share at origination over the business cycle ${ }^{a}$

\begin{tabular}{|c|c|c|c|c|c|c|}
\hline Variables & 1 & 2 & 3 & 4 & 5 & 6 \\
\hline RECESSION & $\begin{array}{r}0.01 \\
(0.89)\end{array}$ & $\begin{array}{r}0.01 \\
(0.91)\end{array}$ & $\begin{array}{r}0.00 \\
(0.35)\end{array}$ & & & \\
\hline RECESSION9091 & & & & $\begin{array}{c}0.03^{*} \\
(1.67)\end{array}$ & $\begin{array}{r}0.05^{* * *} \\
(3.05)\end{array}$ & $\begin{array}{r}0.03 \\
(1.20)\end{array}$ \\
\hline RECESSION01 & & & & $\begin{array}{r}-0.03 \\
(-1.31)\end{array}$ & $\begin{array}{r}-0.03^{* *} \\
(-2.11)\end{array}$ & $\begin{array}{r}-0.01 \\
(-0.69)\end{array}$ \\
\hline RECESSION0809 & & & & $\begin{array}{r}0.04^{* * *} \\
(3.29)\end{array}$ & $\begin{array}{c}0.02^{* *} \\
(2.10)\end{array}$ & $\begin{array}{r}-0.00 \\
(-0.10)\end{array}$ \\
\hline constant & $\begin{array}{r}0.87^{* * *} \\
(11.71)\end{array}$ & $\begin{array}{r}1.18^{* * *} \\
(9.12)\end{array}$ & $\begin{array}{r}1.34^{* * *} \\
(3.71)\end{array}$ & $\begin{array}{r}1.02^{* * *} \\
(13.49)\end{array}$ & $\begin{array}{r}1.18^{* * *} \\
(8.94)\end{array}$ & $\begin{array}{r}1.31^{* * *} \\
(3.53)\end{array}$ \\
\hline Observations & 4830 & 4830 & 4830 & 4830 & 4830 & 4830 \\
\hline R-squared & 0.347 & 0.498 & 0.959 & 0.311 & 0.502 & 0.960 \\
\hline Bank FE & NO & YES & NO & NO & YES & NO \\
\hline Bank-Firm FE & $\mathrm{NO}$ & $\mathrm{NO}$ & YES & $\mathrm{NO}$ & $\mathrm{NO}$ & YES \\
\hline
\end{tabular}

${ }^{a}$ The dependent variable in this table is the arranger loan share at the time of the loan origination. RECESSION is a dummy variable equal to one for the three recessions as classified by NBER during our sample period (1988-2013). RECESSION9091, RECESSION01 and RECESSION0809 are dummy variables for the recessions that occurred in 1990/91, 2001 and 2008/09, respectively. All of the models include the sets of borrower-, loan-, and bank-specific factors reported in Table 1 as well as dummy variables to account for the borrower activity as defined by 1-digit SIC codes. Models estimated with robust standard errors clustered by bank and by firm. We report t statistics in parentheses. *** denotes $1 \%$ significant level, ${ }^{* *}$ denotes $5 \%$ significant level, and * denotes $10 \%$ significant level. 
Table 12 Cuts around the failure of a syndicate member bank ${ }^{a}$

\begin{tabular}{lrrrrrr}
\hline \hline & \multicolumn{3}{c}{ Likelihood of cut } & \multicolumn{3}{c}{ Log of one plus cut } \\
\hline Variables & \multicolumn{1}{c}{1} & \multicolumn{1}{c}{3} & 4 & \multicolumn{1}{c}{5} \\
\hline FAILURE & 0.03 & & & $0.44^{*}$ & & \\
FAILURE0 & $(1.24)$ & & & $(1.86)$ & & \\
& $0.09^{* *}$ & $0.14^{* * *}$ & $0.14^{* * *}$ & $1.04^{* *}$ & $1.56^{* * *}$ & $1.59^{* * *}$ \\
FAILURE1 & $(2.51)$ & $(3.75)$ & $(3.73)$ & $(2.53)$ & $(4.18)$ & $(4.21)$ \\
& 0.02 & 0.03 & 0.03 & 0.10 & 0.24 & 0.22 \\
LLEADUP & $(0.63)$ & $(0.95)$ & $(0.84)$ & $(0.27)$ & $(0.68)$ & $(0.62)$ \\
& $-0.01^{* * *}$ & $-0.01^{* * *}$ & $-0.01^{* * *}$ & $-0.14^{* * *}$ & $-0.12^{* * *}$ & $-0.12^{* * *}$ \\
FAILURE-1xLLEADUP & $(-38.35)$ & $(-25.53)$ & $(-25.33)$ & $(-38.04)$ & $(-24.62)$ & $(-24.28)$ \\
& -0.00 & 0.00 & 0.00 & -0.04 & 0.02 & 0.02 \\
FAILURE0xLLEADUP & $(-0.25)$ & $(0.85)$ & $(0.82)$ & $(-1.18)$ & $(0.28)$ & $(0.27)$ \\
& $-0.02^{* * *}$ & $-0.01^{* *}$ & $-0.01^{* * *}$ & $-0.20^{* * *}$ & $-0.15^{* * *}$ & $-0.15^{* * *}$ \\
FAILURE1xLLEADUP & $(-4.33)$ & $(-2.57)$ & $(-2.62)$ & $(-4.76)$ & $(-3.31)$ & $(-3.37)$ \\
& -0.00 & 0.00 & 0.00 & -0.02 & 0.00 & 0.00 \\
LEADSH & $(-0.10)$ & $(0.30)$ & $(0.32)$ & $(-0.28)$ & $(0.07)$ & $(0.09)$ \\
& $-0.09^{* * *}$ & $-0.24^{* * *}$ & $-0.25^{* * *}$ & $-1.10^{* * *}$ & $-2.34^{* * *}$ & $-2.39^{* * *}$ \\
BK FAILSH & $(-6.14)$ & $(-11.59)$ & $(-11.54)$ & $(-8.22)$ & $(-10.89)$ & $(-10.77)$ \\
& 0.15 & -0.35 & -0.34 & 0.38 & $-4.51^{*}$ & $-4.33^{*}$ \\
UNUSEDRAT & $(0.62)$ & $(-1.46)$ & $(-1.37)$ & $(0.15)$ & $(-1.83)$ & $(-1.69)$ \\
& $-0.15^{* * *}$ & $-0.07^{* * *}$ & $-0.06^{* * *}$ & $-1.33^{* * *}$ & $-0.62^{* * *}$ & $-0.61^{* * *}$ \\
constant & $(-24.06)$ & $(-9.12)$ & $(-8.94)$ & $(-23.57)$ & $(-8.41)$ & $(-8.24)$ \\
& $0.89^{* * *}$ & $-1.49^{* * *}$ & $-1.58^{* * *}$ & $5.43^{* * *}$ & $-20.34^{* * *}$ & $-21.17^{* * *}$ \\
Observations & $(16.32)$ & $(-8.43)$ & $(-7.18)$ & $(10.57)$ & $(-11.24)$ & $(-9.44)$ \\
R-squared & 63079 & 63079 & 63079 & 63079 & 63079 & 63079 \\
Credit line FE & 0.133 & 0.555 & 0.492 & 0.129 & 0.525 & 0.464 \\
Bank FE & $\mathrm{NO}$ & YES & YES & NO & YES & YES \\
\hline \hline
\end{tabular}

${ }^{a}$ Dependent variable in models (1) through (3) is a dummy variable on whether the credit line experiences a reduction during the year. Dependent variable in models (4) through (6) is the log of one plus the reduction in the size of the credit line during the year. FAILURE is a dummy variable for the credit lines that experience a failure of a syndicate member bank. FAILURE0 and FAILURE1 are dummy variable for the year in which the failure occurs and the year after. The control group is the year before the failure. Included in the regressions are dummy variables for the remaining years of the credit line. LLEADUP is the log of one plus the additional dollar amount investment the lead arranger does on the credit line over the year. LEADSH is the lagged share of the credit line retained by the lead arranger BK FAILSH is the lagged share of the credit line owned by the $\operatorname{bank}(\mathrm{s})$ that fail prior to the year of failure. UNUSEDRAT is the lagged portion of the credit line that was still undrawn. All of the models include the sets of loan-, and bank-specific factors reported in Table 1 as well as dummy variables to account for the borrower activity as defined by 1-digit SIC codes, and year dummy variables. Models estimated with robust standard errors. We report t statistics in parentheses. ${ }^{* * *}$ denotes $1 \%$ significant level, ${ }^{* *}$ denotes $5 \%$ significant level, and * denotes $10 \%$ significant level. 


\section{References}

Acharya, V., Almeida, H., and Campello, M. (2013). Credit lines as monitored liquidity insurance: Theory and evidence. Journal of Finance, 68:2059-2116.

Acharya, V., Almeida, H., and Ippolito, F. (2012). Credit lines as monitored liquidity insurance: Theory and evidence. Journal of Financial Economics, 112(3):287-319.

Agarwal, S., Chomsisengphet, S., and Driscoll, J. (2004). Loan commitments and private firms. Board of Governors of the Federal Reserve System, Working Paper.

Berrospide, J. (2012). Liquidity hoarding and the financial crisis: An empirical evaluation. Board of Governors of the Federal Reserve, Working Paper.

Board, S. (2011). Relational contracts and value of loyalty. American Economic Review, 101(7):33493367.

Bord, V. and Santos, J. (2012). The rise of the originate-to-distribute model and the role of banks in financial intermediation. Federal Reserve Bank of New York Economic Policy Review, pages 21-34.

Bord, V. and Santos, J. (2014). Banks' liquidity and the cost of liquidity to corporations. Journal of Money, Credit and Banking, 46(1):13-45.

Campello, M., Giambona, E., Graham, J., and Harvey, C. (2011). Liquidity management and corporate investment during a financial crisis. The Review of Financial Studies, 24(6):1944-1979.

Campello, M., Graham, J., and Harvey, C. (2010). The real effects of credit constraints: Evidence from a financial crisis. Journal of Financial Economics, 97(3):470-487.

Chava, S. and Jarrow, R. (2008). Modeling loan commitments. Finance Research Letters, 5:11-20.

Chen, Z., Hu, Y., John, K., and Mao, C. (2017). How much liquidity insurance do credit lines provide? SSRN, Working Paper.

Chodorow-Reich, G. and Falato, A. (2018). The loan covenant channel: How bank health transmits to the real economy. Working Paper, Harvard University.

Demiroglu, C., James, C., and Kizilaslan, A. (2012). Bank lending standards and access to lines of credit. Journal of Money, Credit, and Banking, 44(6):1063-1089. 
Flannery, M. and Lockhart, B. (2009). Credit lines and the substitutability of cash and debt. Working Paper, University of Florida.

Gao, P. and Yun, H. (2009). Commercial paper, lines of credit, and the real effects of the financial crisis of 2008: Firm-level evidence from the manufacturing industry. Working Paper, Notre Dame University.

Gatev, E. and Strahan, P. (2006). Banks' advantage in hedging liquidity risk: Theory and evidence from the commercial paper market. Journal of Finance, 61:867-892.

Ham, J. and Melnik, A. (1987). Loan demand: An empirical analysis using micro data. Review of Economics and Statistics, 69:704-709.

Holmstrom, B. and Tirole, J. (1997). Private and public supply of liquidity. Journal of Political Economy, 106(1):1-40.

Huang, R. (2010). How committed are bank lines of credit? experiences in the subprime mortgage crisis. Federal Reserve Bank of Philadelphia, Working Paper.

Ivashina, V. and Scharfstein, D. (2010a). Bank lending during the financial crisis of 2008. Journal of Financial Economics, 97(3):319-338.

Ivashina, V. and Scharfstein, D. (2010b). Loan syndication and credit cycles. American Economic Review Papers and Proceedings, 100(2):57-61.

Jiménez, G., Lopez, J., and Saurina, J. (2009). Empirical Analysis of Corporate Credit Lines. Review of Financial Studies, 22(12):5069-5098.

Kizilaslan, A. and Mathers, A. (2014). Strategic credit line usage and performance. Journal of Financial Research, 37(2):243-265.

Lins, K., Servaes, H., and Tufano, P. (2010). What drives corporate liquidity? an international survey of cash holdings and lines of credit. Journal of Financial Economics, 98(1):160-176.

Norden, L. and Weber, M. (2010). Credit Line Usage, Checking Account Activity, and Default Risk of Bank Borrowers. Review of Financial Studies, 23(10):3665-3699.

Paligorova, T. and Santos, J. (2019). The side eects of shadow banking on liquidity provision. SSRN, Working Paper. 
Rampini, A. and Viswanathan, S. (2019a). Financial intermediary capital. Review of Economic Studies, 86(1):413-445.

Rampini, A. and Viswanathan, S. (2019b). Financing insurance. Duke University, Working Paper.

Ray, D. (2002). The time structure of self-enforcing agreements. Econometrica, 70:547-582.

Roberts, M. and Sufi, A. (2009). Renegotiation of financial contracts: Evidence from private credit agreements. Journal of Financial Economics, 93:159-184.

Schwert, M. (2020). Does borrowing from banks cost more than borrowing from the market? Journal of Finance, 75(2):905-947.

Shockley, R. and Thakor, A. (1997). Bank loan commitment contracts: Data, theory and tests. Journal of Money, Credit, and Banking, 29(4):517-534.

Sufi, A. (2009). Bank lines of credit in corporate finance: An empirical analysis. Review of Financial Studies, 22(3):1057-1088.

Yun, H. (2009). The choice of corporate liquidity and corporate governance. Review of Financial Studies, 22(4):1447-1475. 


\section{Appendix A: Proofs}

Proof of Proposition 1: It is clear that the zero profit constraint (Equation 8) for banks must bind, hence $\lambda_{F}>0$, thus (here $N^{*}$ is the first best syndicate size)

$$
p L(R-r)+C=p q m\left(\frac{L}{N^{*}}\right) L+\left(N^{*}-1\right) x
$$

which says that the expected revenues to the syndicate must be equal to the expected costs. The first order condition with respect to $N$ can be rewritten as

$$
-p q m^{\prime}\left(\frac{L}{N^{*}}\right) \frac{L^{2}}{\left(N^{*}\right)^{2}}+x=0
$$

and the second order condition

$$
p q\left(m^{\prime}\left(\frac{L}{N^{*}}\right) \frac{2 L^{2}}{\left(N^{*}\right)^{3}}+m^{\prime \prime}\left(\frac{L}{N^{*}}\right) \frac{L^{3}}{\left(N^{*}\right)^{4}}\right)>0
$$

and thus there is a unique perfectly competitive maximum (first best). Further since $H_{R}(0)>G_{C}>0$, we must have $C>0$ and $R=r$; it is cheaper to put the cost of providing the first best loan commitment in the commitment fee rather than the interest rate; hence the interest rate will be $r$. Thus the commitment fee is given by

$$
C=\operatorname{pqm}\left(\frac{L}{N^{*}}\right) L+\left(N^{*}-1\right) x
$$

Proof of Proposition 2; This is a standard convex programming problem with an objective being minimized that is convex in $C$ and $R$ and a constraint set that is affine in $R$ and $C$ and convex in $N$. The first order conditions are:

$$
\begin{array}{cc}
\text { (w.r.t to R) } & H_{R}(p(R-r) L) p L-\lambda L-\lambda p L \frac{\delta}{1-\delta}-\mu=0 \\
\text { (w.r.t to C) } & G_{C}(C)-\lambda \frac{\delta}{1-\delta}-\gamma=0 \\
\text { (w.r.t to N) } & \lambda\left[-\frac{\delta}{1-\delta} p q m^{\prime}\left(\frac{L}{N}\right) \frac{L^{2}}{N^{2}}+\frac{\delta}{1-\delta} x-m^{\prime}\left(\frac{L}{N}\right) \frac{L^{2}}{N^{2}}\right]=0
\end{array}
$$

plus the complementary slackness conditions that

$$
\lambda\left[-(R-r) L \frac{1-(1-p) \delta}{1-\delta}-\frac{\delta}{1-\delta}\left[C-p q m\left(\frac{L}{N}\right) L-(N-1) x\right]+m\left(\frac{L}{N}\right) L\right]=0
$$


plus $\mu(R-r)=0$ and $\gamma C=0$. It is clear that the participation constraint must bind and $\lambda>0$, hence (here $\hat{N}$ is the second best syndicate size):

$$
(R-r) L \frac{1-(1-p) \delta}{1-\delta}+\frac{\delta}{1-\delta}\left[C-p q m\left(\frac{L}{\hat{N}}\right) L-(\hat{N}-1) x\right]=m\left(\frac{L}{\hat{N}}\right) L
$$

First we note that $\hat{N}>N^{*}$ (more syndicate members) because Equation 38 can be rewritten as

$$
p q m^{\prime}\left(\frac{L}{\hat{N}}\right) \frac{L^{2}}{(\hat{N})^{2}}+\frac{1-\delta}{\delta} m^{\prime}\left(\frac{L}{\hat{N}}\right) \frac{L^{2}}{(\hat{N})^{2}}=x
$$

where the second term in Equation (41) did not exist without participation constraints (compare to Equation (33) and is a positive term (the left hand side is decreasing in $N$ and the right hand side is a constant). Hence $\hat{N}>N^{*}$ follows. Note that increasing $L$ increases $\hat{N}$.

The first order conditions in Equations $(36)$ and (37) can be merged to obtain:

$$
\frac{H_{R}(p(R-r) L)}{\frac{1-(1-p) \delta}{p(1-\delta)}} \geq \frac{G_{C}(C)}{\frac{\delta}{1-\delta}}
$$

To obtain tighter results we make the following assumption ${ }^{30}$ If we assume that

$$
\frac{H_{R}(0)}{G_{C}}>\frac{1-(1-p) \delta}{p \delta}>1
$$

for all $\delta$, we still obtain $R=r$ and $C>0$.

We can then show the following; the profit condition implies

$$
\begin{aligned}
& p L(R-r)+C \\
& \left.>p q m\left(\frac{L}{\hat{N}}\right) L+(\hat{N}-1) x\right) \text { because expected revenues exceed costs } \\
& \left.>p q m\left(\frac{L}{N^{*}}\right) L+\left(N^{*}-1\right) x\right) \text { because costs are minimized at } N^{*}
\end{aligned}
$$

\footnotetext{
${ }^{30}$ There is an tension between increasing $R$ and increasing $C$ in the second best. From an incentive perspective it is easier to increase $R$, but from a firm utility perspective, increases in $C$ are preferable to increases in $R$ since the firm wants insurance in the interest rate. In Equation this incentive issues shows up as

$$
\frac{1}{\frac{1-(1-p) \delta}{p(1-\delta)}}>\frac{1}{\frac{\delta}{1-\delta}}
$$

and reflects the fact that increasing $R$ directly improves the ex post participation constraint, the syndicate member is more likely to participate. If our condition we provide does not hold $\hat{R}>r$ and most likely $C>c$.
} 
which basically states that the budget line must move outwards and given our assumptions that $\frac{H_{R}(0)}{G_{C}}>$ $\frac{1-(1-p) \delta}{p \delta}$, we obtain that $\hat{C}>C$ and $\hat{R} \geq R$.

\section{Proof of Proposition 3}

To provide comparative statics, we rewrite Equation [41] as

$$
p q m^{\prime}(\phi)(\phi)^{2}+\frac{1-\delta}{\delta} m^{\prime}(\phi)(\phi)^{2}=x
$$

for $\phi=\frac{L}{N}$; thus only the ratio is identified. Clearly if $p^{+}>p$, then $\phi=L / N$ must fall, hence the number of syndicate members must go up (since $L$ is fixed). A similar argument holds for $q^{+}>q$. If $\delta^{+}<\delta$, we must have that $\hat{\phi}^{+}>\hat{\phi}$ which implies that for fixed $L, \hat{N}^{+}>\hat{N}$.

Proof of Proposition 4 4 The first order conditions for the maximization are:

$$
\begin{aligned}
& \text { (w.r.t to R) } \left.\quad H_{R}(p(R-r) L) p L-\lambda_{m} p 1+p d^{L}\right] L_{m}-\lambda_{n}\left[1+p d^{N L}\right] L_{n}-\mu=0 \\
& \text { (w.r.t to } \left.C_{m}\right) \quad G_{C}(C)-\lambda_{m} d^{L}-\gamma_{m}=0 \\
& \text { (w.r.t to } \left.C_{n}\right) \quad G_{C}(C)-\lambda_{n} d^{N L}-\gamma_{n}=0 \\
& (\text { w.r.t to } N) \quad-\lambda_{n}\left[1+d^{N L} p q\right] n^{\prime}\left(\frac{L_{n}}{N-1}\right) \frac{L_{n}^{2}}{(N-1)^{2}}+\lambda_{m} d^{L} x=0 \\
& \text { (w.r.t to } \left.L_{n}\right) \quad \lambda_{m}\left[(R-r)\left(1+d^{L} p\right)-\left(1+d^{L} p q\right)\left(m\left(L_{m}\right)+m^{\prime}\left(L_{m}\right) L_{m}\right)\right] \\
& -\lambda_{n}\left[(R-r)\left(1+d^{N L} p\right)-\left(1+d^{N L} p q\right)\left(n\left(\frac{L_{n}}{N-1}\right)+n^{\prime}\left(\frac{L_{n}}{N-1}\right) \frac{L_{n}}{N-1}\right)\right]=0
\end{aligned}
$$

Since $\delta^{L}>\delta^{N L}$ (and $d^{L}>d^{N L}$ ), the lead has a higher probability of long run survival and cares for the future more than the non-leads. In this case, using Equations 477 and 48, we obtain that (since $C_{n}>0$ and $C_{m}>0$ )

$$
\lambda_{n}=\lambda_{m} \frac{d^{L}}{d^{N L}} \text { with } \frac{d^{L}}{d^{N L}}>1
$$

which then leads to (assuming $\mathrm{R}=\mathrm{r}$ )

$$
\begin{aligned}
& (\text { w.r.t to } N)\left[\frac{1+d^{N L} p q}{d^{N L}}\right] n^{\prime}\left(\frac{L_{n}}{N-1}\right) \frac{L_{n}^{2}}{(N-1)^{2}} \leq x \\
& \begin{aligned}
\left(\text { w.r.t to } L_{n}\right) & \frac{1+d^{L} p q}{d^{L}}\left[m\left(L_{m}\right)+m^{\prime}\left(L_{m}\right) L_{m}\right] \\
& =\frac{1+d^{N L} p q}{d^{N L}}\left[n\left(\frac{L_{n}}{N-1}\right)+n^{\prime}\left(\frac{L_{n}}{N-1}\right) \frac{L_{n}}{N-1}\right]
\end{aligned}
\end{aligned}
$$


Suppose $d^{N L}$ goes down, then $\frac{1+d^{N L} p q}{d^{N L}}$ goes up and from Equation 51 above, we have that $\frac{L_{n}}{N-1}$ has to go down. However from Equation 51 then, if given that $n(t)=t^{\gamma}, \gamma>1$, we obtain that the right hand side of Equation $\sqrt{52}$ above becomes $\frac{x(1+(1 / \gamma))}{\left(L_{n} /(N-1)\right)}$ and consequently $L_{m}$ has to go up. So the lead commitment and the lead share has to go up if the discount rate of the non-leads goes down.

What happens to the commitment fees $C_{m}$ and $C_{n}$. If we set $R=r$ to simplify, then using Equations 20 and 22 we obtain that

$$
\frac{C_{n}}{N-1}=\frac{1+d^{N L} p q}{d^{N L}} n\left(\frac{L_{n}}{N-1}\right) \frac{L_{n}}{N-1}=\frac{x}{\gamma} \text { if } n(t)=t^{\gamma}, \gamma>1
$$

Hence the non-lead commitment fees stay the same. However the lead commitment fees goes up given a fixed syndicate size $N$ as Equation 52 yields that

$$
\left(\frac{1}{d^{L}}+p q\right)\left[m\left(L_{m}\right)+m^{\prime}\left(L_{m}\right) L_{m}\right]=\frac{x(1+\gamma)}{\left(L_{n} /(N-1)\right)}
$$

and since the right hand side goes up and $d^{L}$ is constant, we have already shown that $L_{m}$ must go up and thus we obtain that

$$
\left.C_{m}=\left(\frac{1}{d^{L}}+p q\right)\left(m\left(L_{m}\right) L_{m}+(N-1) x\right)\right)
$$

the lead's commitment fee must go up given $N$. Thus given a fixed syndicate size both the lead commitment fee $C_{m}$ and the total commitment fee $C_{m}+C_{n}$ go up.

If $L_{m}<\psi L_{n}$, then the number of non-lead syndicate members must increase in response to the change $\Delta \delta^{N L}<0$ and then we can show using Equation 55 that $C_{m}$ goes up and also $C_{m}+C_{n}$ goes up 31

\footnotetext{
${ }^{31}$ If the condition does not hold then, the incentive effect raises the commitment fee but the number of non-leads falls, making the syndicate fixed cost lower, which is a countervailing effect. In the data, the condition $L_{m}<\psi L_{n}$ is met.
} 


\section{Appendix B: Variable Definitions}

This table provides definitions of the variables used in the empirical analysis.

\begin{tabular}{|c|c|c|}
\hline VARIABLE & DEFINITION & SOURCE \\
\hline \multicolumn{3}{|c|}{ FIRM CONTROLS } \\
\hline$S A L E S$ & Sales in billions dollars & Compustat \\
\hline$L E V E R A G E$ & Debt over assets & Compustat \\
\hline MKTOBOOK & Market to book value & Compustat \\
\hline$P R O F M A R G I N$ & Net income over sales & Compustat \\
\hline$L I N T C O V$ & Log of interest coverage truncated at 0 & Compustat \\
\hline$L I Q U I D I T Y$ & Cash over asset & Compustat \\
\hline$T A N G I B L E S$ & Share of assets in tangibles & Compustat \\
\hline RELATIONSHIP & $\begin{array}{l}\text { Dummy variable equal to one if the borrower took out loans from the lead } \\
\text { bank over the past three years }\end{array}$ & Dealscan \\
\hline$R \& D$ & Research and development expenses over sales & Compustat \\
\hline$A D V E R T I S I N G$ & Advertising expenses over sales & Compustat \\
\hline$S T O C K V O L$ & Standard deviation of the borrower's stock return & CRSP \\
\hline$E X R E T$ & Return on the borrower's stock over the market return & CRSP \\
\hline$A A, A A, \ldots C$ & Credit rating of the borrower & Compustat \\
\hline \multicolumn{3}{|c|}{ LOAN CONTROLS } \\
\hline$A L L-I N-D R A W N$ & All-in-drawn spread on the credit line at origination & Dealscan \\
\hline$A M O U N T$ & Loan amount in million dollars & Dealscan \\
\hline$C P B C K U P$ & Dummy variable equal to 1 if the credit line is for a $\mathrm{CP}$ program & Dealscan \\
\hline$C U T$ & $\begin{array}{l}\text { Dummy variable equal to } 1 \text { if the credit line experiences a reduction in its size } \\
\text { over the year }\end{array}$ & $\mathrm{SNC}$ \\
\hline$D E B T R E P A Y$ & Dummy variable equal to 1 if the credit line is to repay existing debt & Dealscan \\
\hline$D I V I D E N D R E S T$ & Dummy variable equal to 1 if there are dividend restrictions & Dealscan \\
\hline$D G$ & $\begin{array}{l}\text { Dummy variable equal to } 1 \text { if the lead arranger downgrades the credit line } \\
\text { rating over the year }\end{array}$ & $\mathrm{SNC}$ \\
\hline$D R A W A M T$ & Amount the borrower drew down on the credit line over the year & $\mathrm{SNC}$ \\
\hline$D R A W N R A T E$ & Percentage of the credit line already drawn down & $\mathrm{SNC}$ \\
\hline$F A I L U R E$ & $\begin{array}{l}\text { Dummy variable equal to } 1 \text { there was a failure of a syndicate member bank } \\
\text { over the year }\end{array}$ & FDIC \\
\hline$F A I L U R E S H$ & $\begin{array}{l}\text { Percentage of the crerdit line the failed bank(s) owned at yearend prior to its } \\
\text { failure }\end{array}$ & $\mathrm{SNC}$ \\
\hline$F U L L Y D R A W N$ & $\begin{array}{l}\text { Dummy variable equal to } 1 \text { for credit lines with a drawdown rate equal or } \\
\text { larger than } 95 \%\end{array}$ & $\mathrm{SNC}$ \\
\hline$G U A R A N T O R$ & Dummy variable equal to 1 if the borrower has a guarantor & Dealscan \\
\hline$L E A D S H$ & Lead arranger's share of the loan & $\mathrm{SNC}$ \\
\hline$L E A D U P$ & $\begin{array}{l}\text { Additional additional dollar amount investment the lead arranger does on the } \\
\text { credit line over the year }\end{array}$ & $\mathrm{SNC}$ \\
\hline$L E N D E R S$ & Number of lenders (including the lead arranger) in the loan syndicate & $\mathrm{SNC}$ \\
\hline$L O A N I G$ & Dummy variable equal to 1 if the loan is rated PASS by the lead arranger & $\mathrm{SNC}$ \\
\hline$M \& A$ & Dummy variable equal to 1 if the credit line is for M\&A activity & Dealscan \\
\hline$M A T U R I T Y$ & Maturity of the loan at origination in years & $\mathrm{SNC}$ \\
\hline$M A T U R I T Y L E F T$ & Maturity left in the loan in years & $\mathrm{SNC}$ \\
\hline
\end{tabular}




\begin{tabular}{|c|c|c|}
\hline VARIABLE & DEFINITION & SOURCE \\
\hline PROJFIN & Dummy variable equal to 1 if the credit line is for project finance & Dealscan \\
\hline$R E F I N A N C E$ & Dummy variable equal to 1 if the loan is to refinance an existing loan & Dealscan \\
\hline$S E C U R E D$ & Dummy variable equal to 1 if the loan is secured & Dealscan \\
\hline$S E N I O R$ & Dummy variable equal to 1 if the loan is senior & Dealscan \\
\hline$U N D R A W N A M T$ & Amount left in the credit line that is still unused & $\mathrm{SNC}$ \\
\hline$U N D R A W F E E$ & Undrawn fee on the credit line at origination & Dealscan \\
\hline$U N D R A W N R A T E$ & Percentage of the credit line still unused & $\mathrm{SNC}$ \\
\hline \multirow[t]{2}{*}{ WORK CAPITAL } & Dummy variable equal to 1 if the credit line is for working capital & Dealscan \\
\hline & BANK CONTROLS & \\
\hline$C A P I T A L b k$ & Shareholders' equity capital over assets & Y9C \\
\hline$A S S E T S b k$ & Bank assets in billion dollars & Y9C \\
\hline$R O A b k$ & Net income over assets & Y9C \\
\hline$R O A V O L$ & Standard deviation of the quarterly ROA computed over the last three years & Y9C \\
\hline$S U B D E B T$ & Subdebt over assets & Y9C \\
\hline \multirow[t]{2}{*}{$L I Q U I D I T Y$} & Cash plus securities over assets & Y9C \\
\hline & MACROECONOMIC CONTROLS & \\
\hline RECESSION90/91 & Dummy variable equal to 1 for years of 1990 and 91 & NBER \\
\hline RECESSION01 & Dummy variable equal to 1 for year 2001 & NBER \\
\hline RECESSION08/09 & Dummy variable equal to 1 for years of 2008 and 2009 & NBER \\
\hline
\end{tabular}

